\title{
أطر معالجة الصحف المصرية لأداء مجلس النواب 2015
}

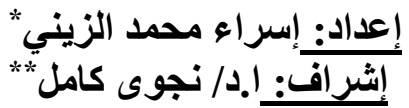

مقتمةت الصحافة منذ نشأتها بدور فعال ومؤثر في تقديم ومناقثة قضايا وأحداث

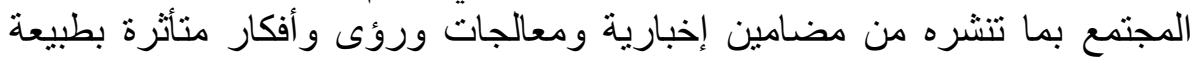

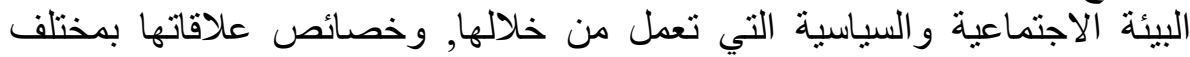

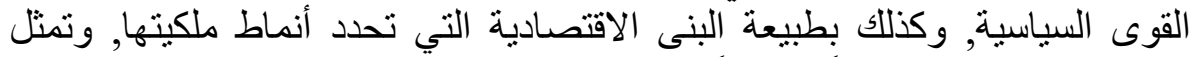

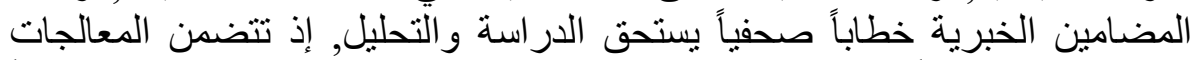

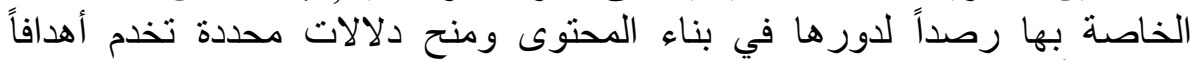

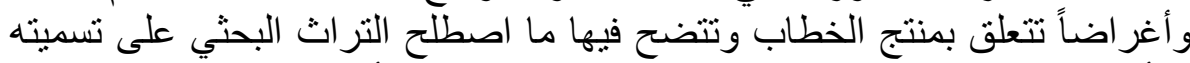

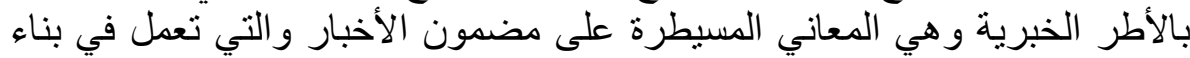

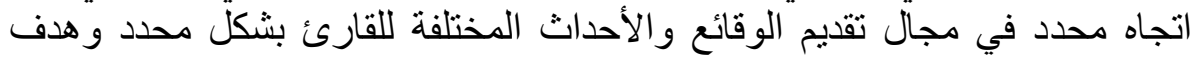

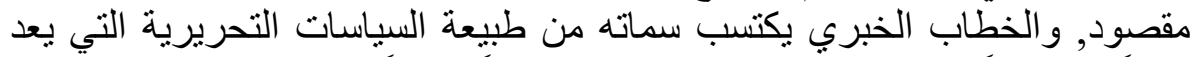

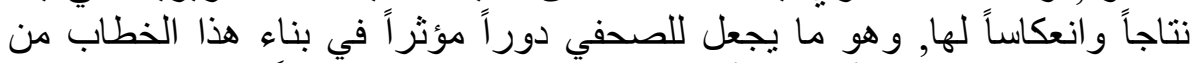

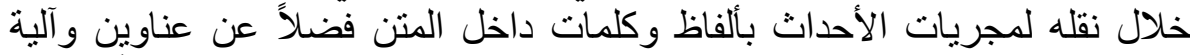

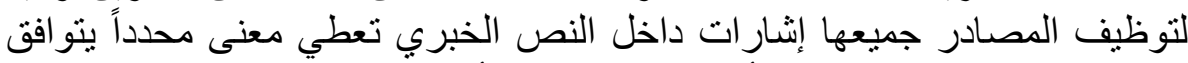

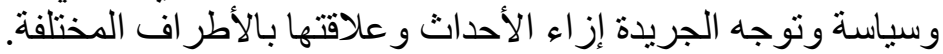

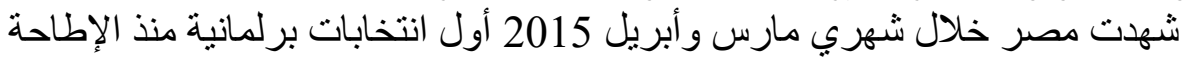

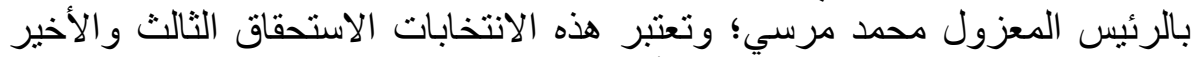

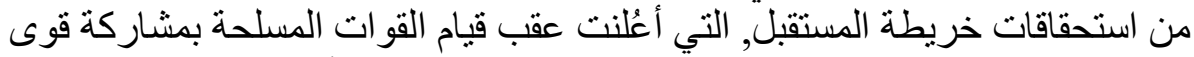

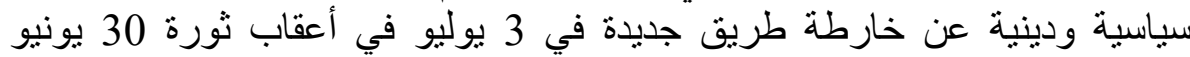

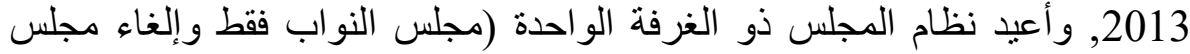

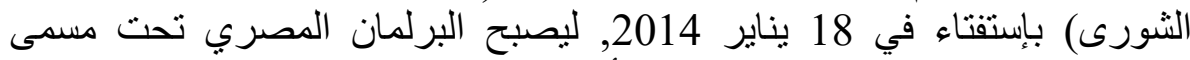

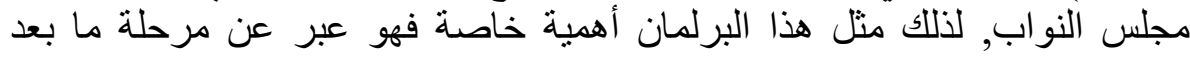

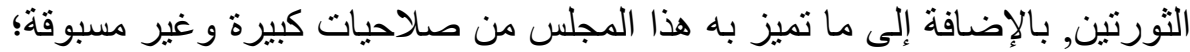

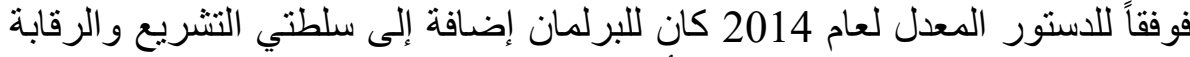

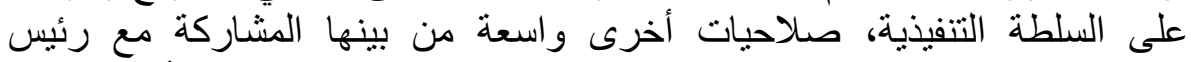
الجمهورية في اختيار رئيس الحكومة، وكذلك إمكانية تشكيل الحزبة الحزب أو أو الائتلاف

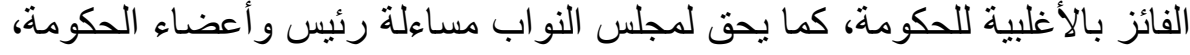

* مدرس مساعد بقسم الصحافة بكلية الإعلام - جامعة القاهرة * الأستاذ بقسم الصحافة بكلية الإعلام - جامعة القاهرة 


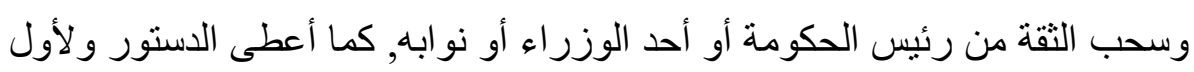

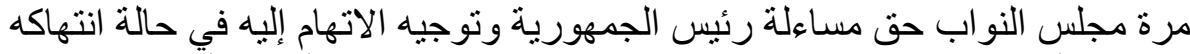

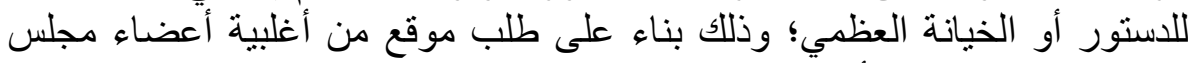

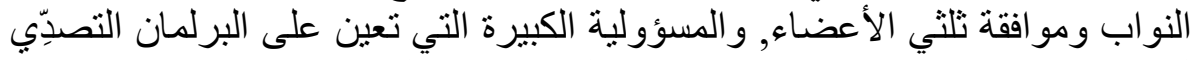

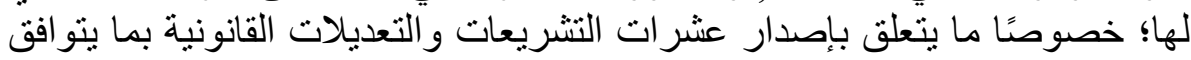
مع الدستور، وقيام هذا البرلمان بإصدار العديد من التشريعات والقوات التين القين المكملة

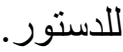
أكدت الدراسات العلمية والتقارير الدور الذي قامت به وسائل الإعلام خلال فترة

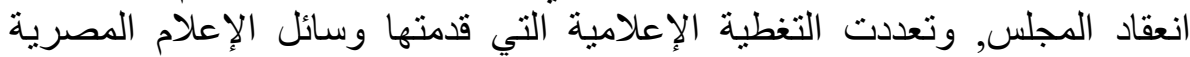

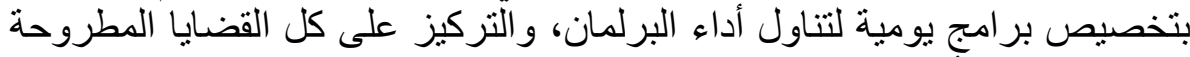

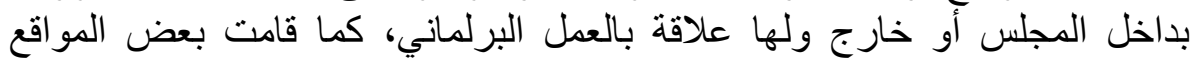

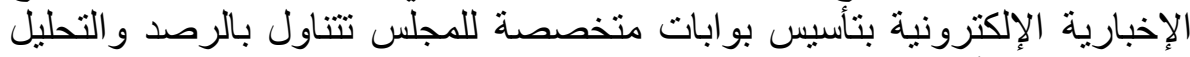

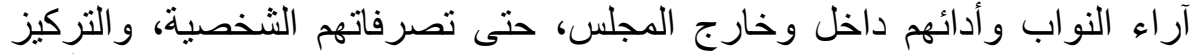

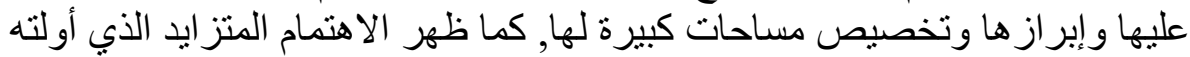

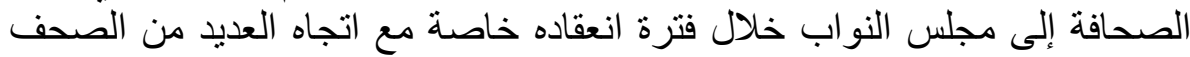

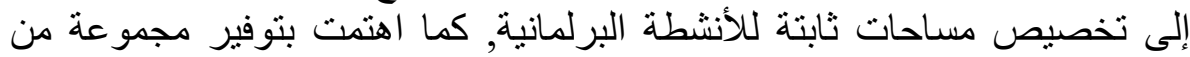

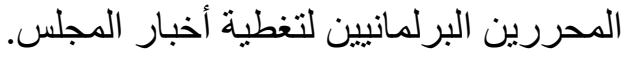

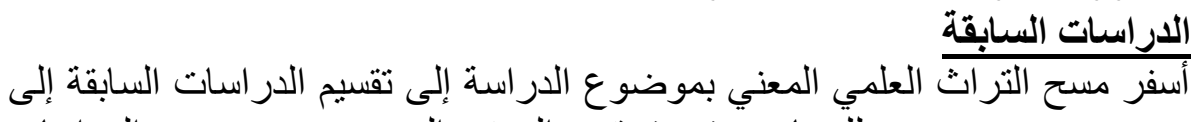

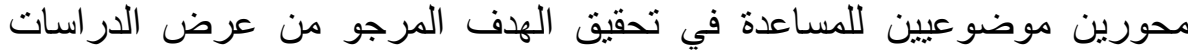

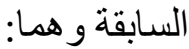
الدر اسات التي اهتمت بالمعالجة الإعلامية للشئون البرلمانية, و الدر اسات التي تناولت

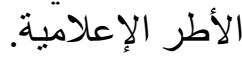
المحور الأول: الارباسات التى اهتمت بالمعالجة الإعلامية للشئون البرلمانية.

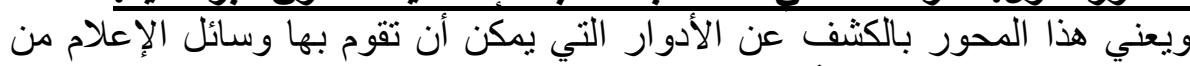

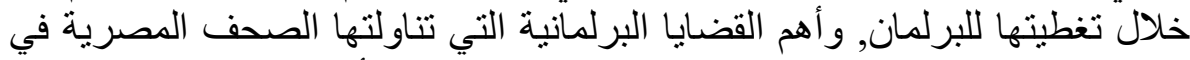

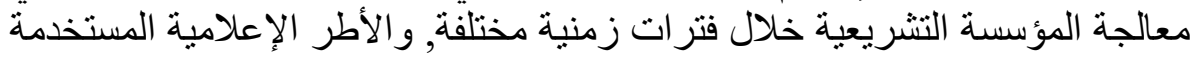

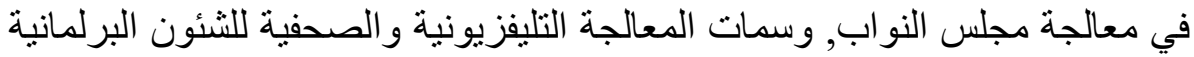

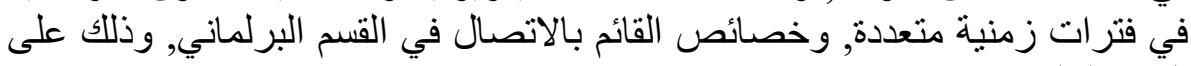
النحو التالي: تصني:

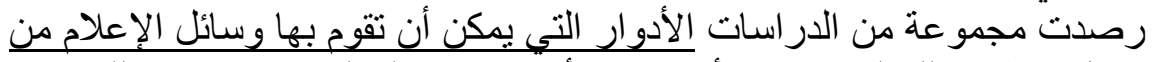

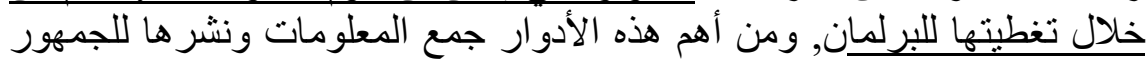

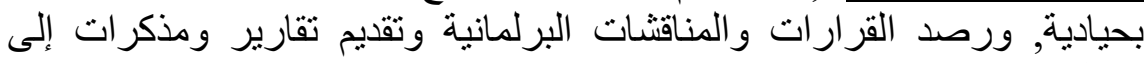

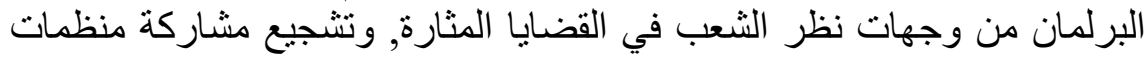

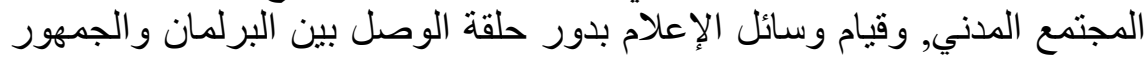


قبل تمرير التشريعات والقوانين من خلال جمع تقارير و عمل استطلاعات للر أي

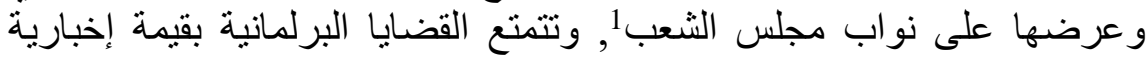

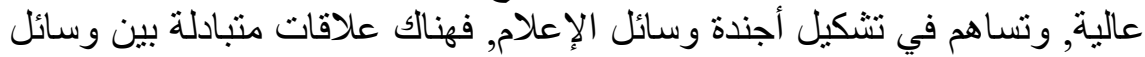

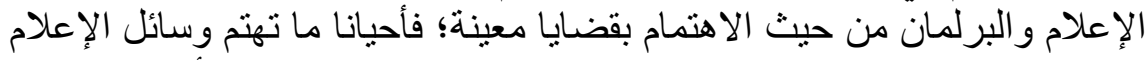

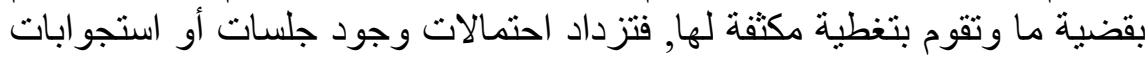

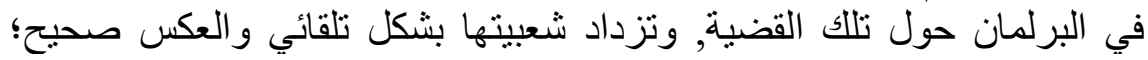

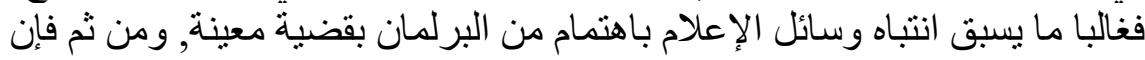

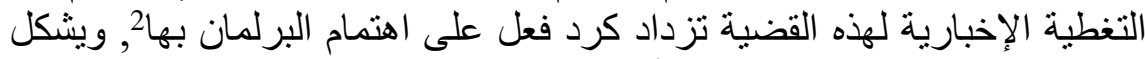

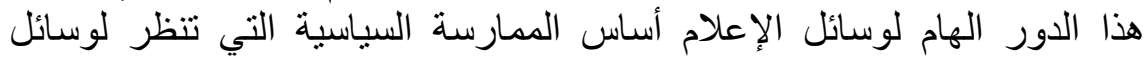
الإعلام على أنها أداة قوية الفعالية, وتعتبر العلاقة السببية بين التغطية الإعلامية التانية

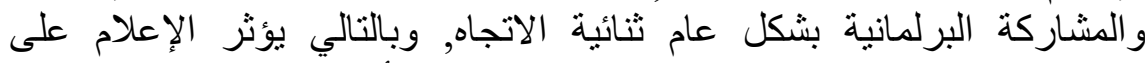

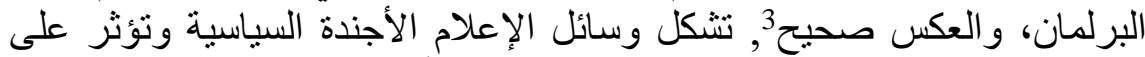
الصورة الذهنية المشكلة لدى الجمهور حيث أظهرت نتائج دراسة الإنة هيمنة

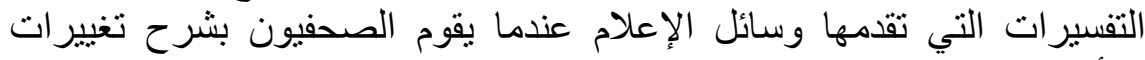

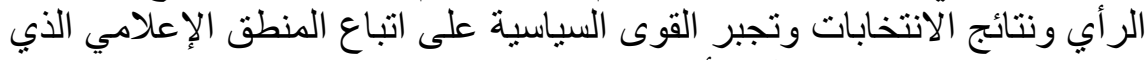

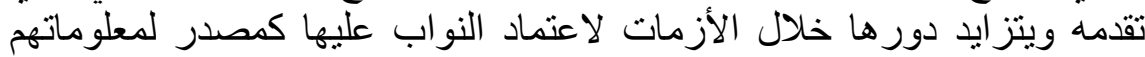

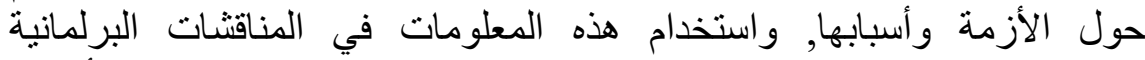

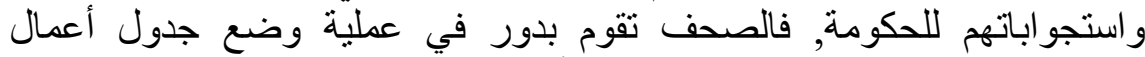

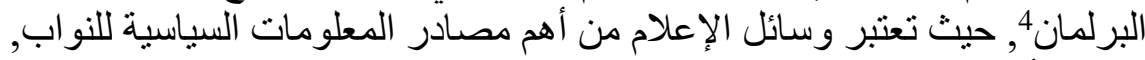

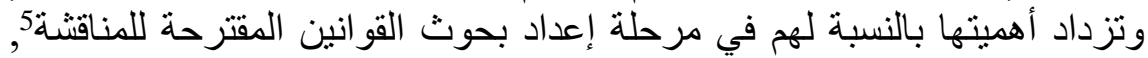

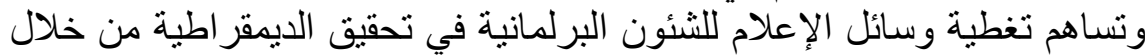

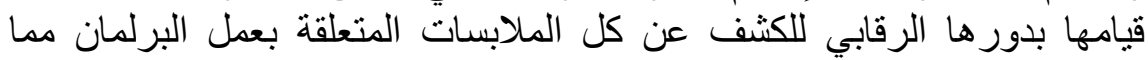

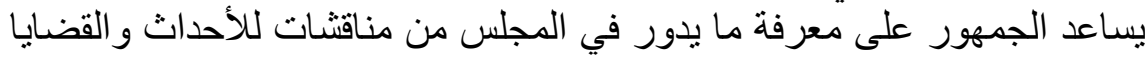
المختلفة6, فالتغطية الإعلامية المحدودة تعزز هيمنة السلطة التنفيذية بينما التغطية

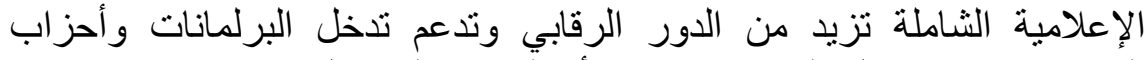

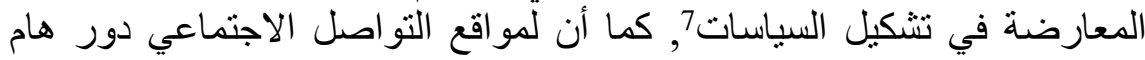

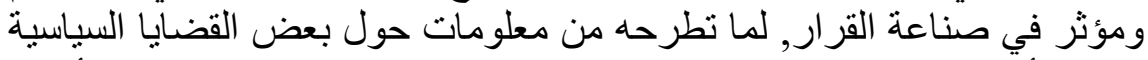

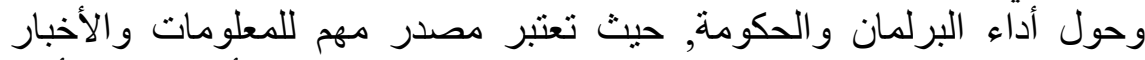

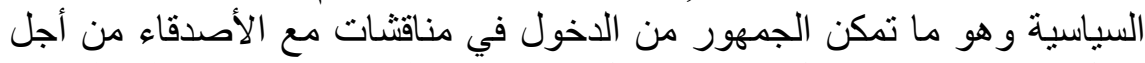

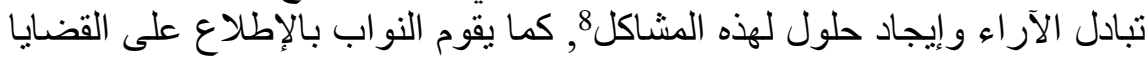

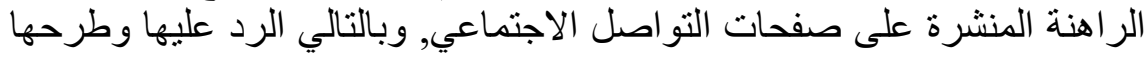

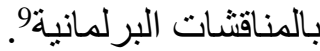

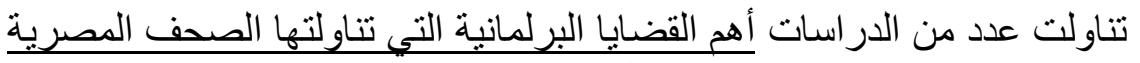

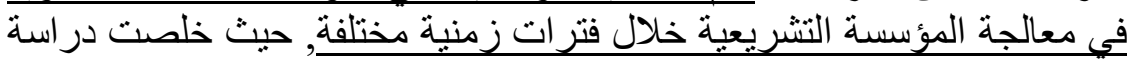

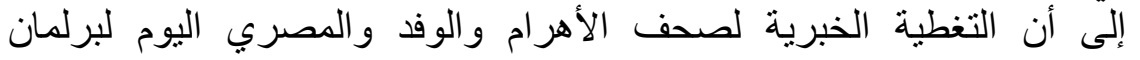


2013/2012 ركزت على قضايا برلمانية أساسية, هي إهدار المال العام, وزئة

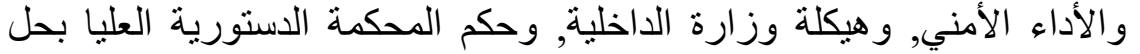

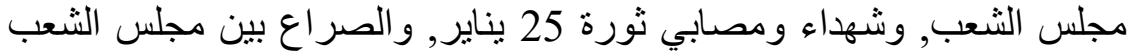

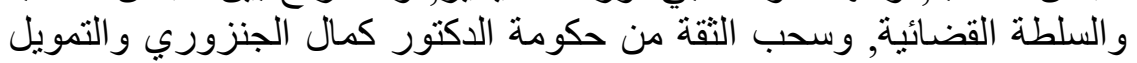

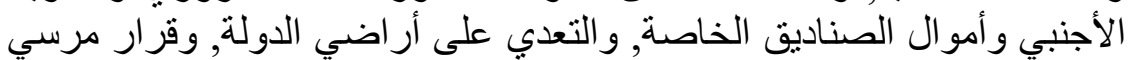

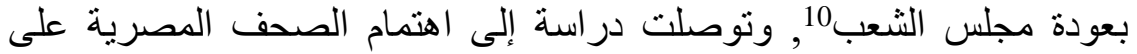

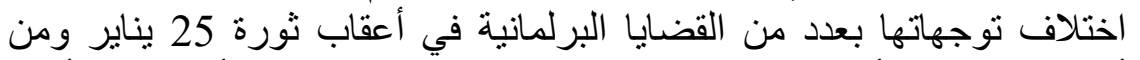

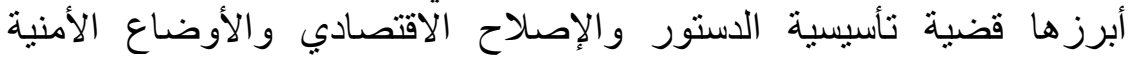

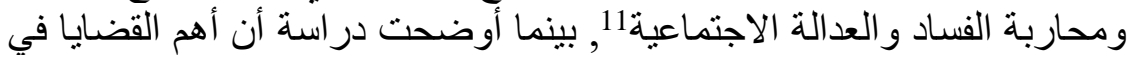
دورة الانعقاد الأول للبرلمان بعد ثورة 30 يوينة من يناير وحتى سبتمبر الإن 2016

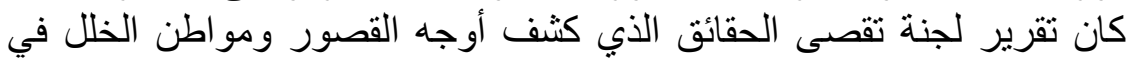

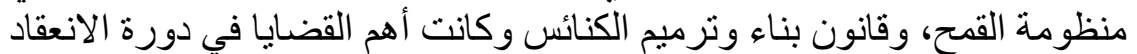

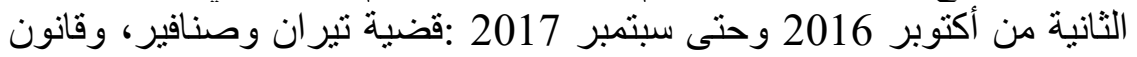

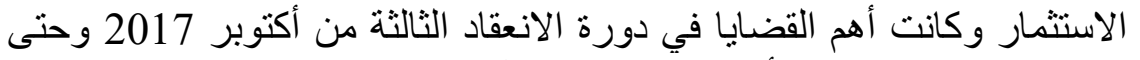

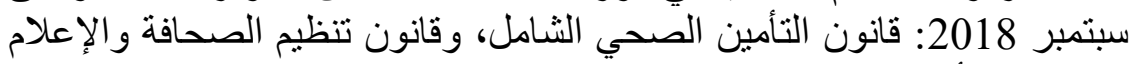

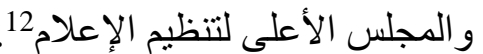

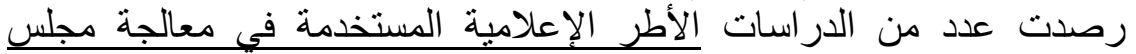

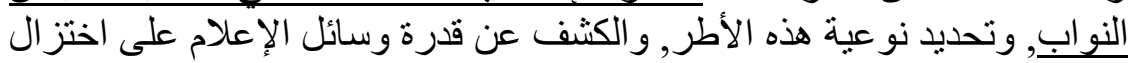

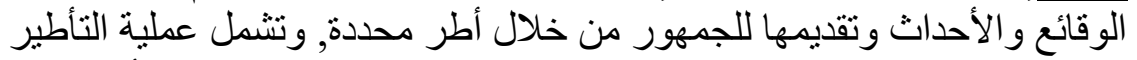

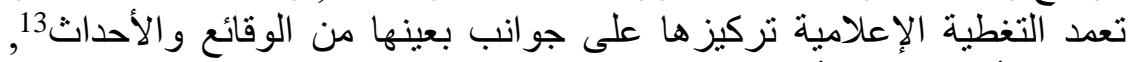

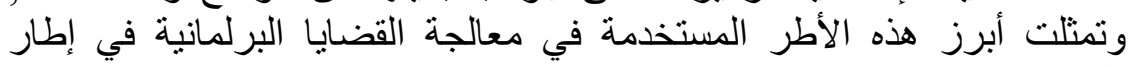

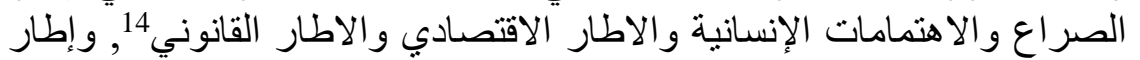

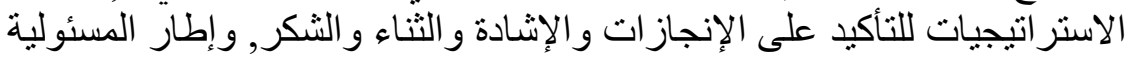

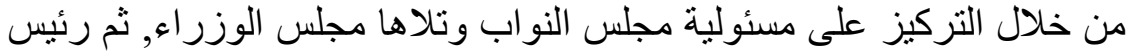

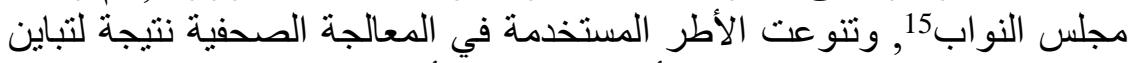

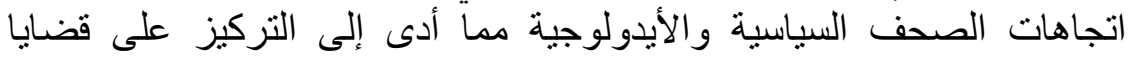

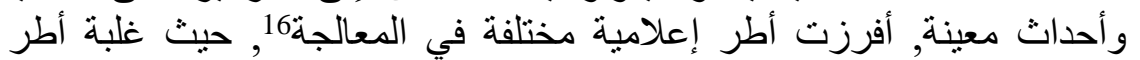

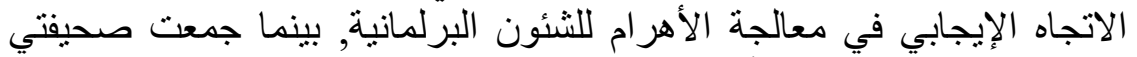

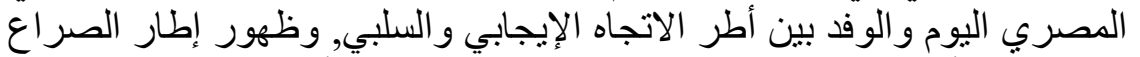

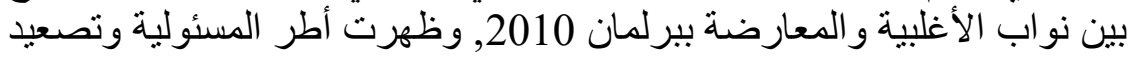

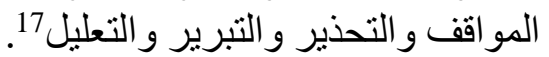

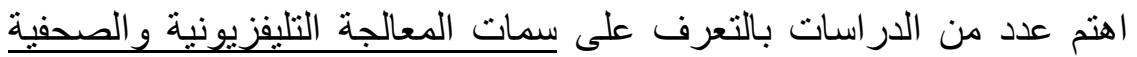

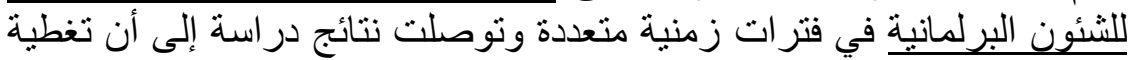

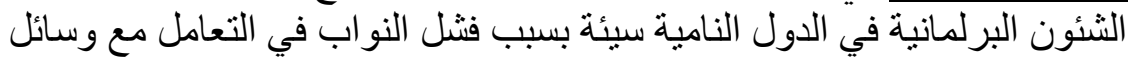

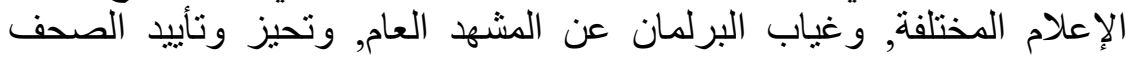


الرسمية للبرلمان من خلال الاعتماد على المصادر الرسمية و عدم تواجد أب البي

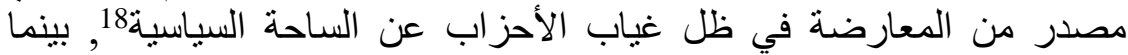
أثنارت دراسة ثانية إلى تميز الصحافة الثية المطبوعة بتقديم تغطية جيدة للثشئون

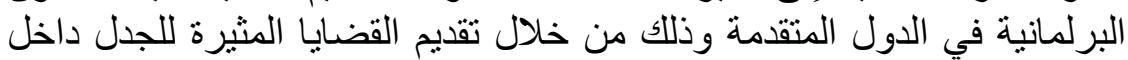

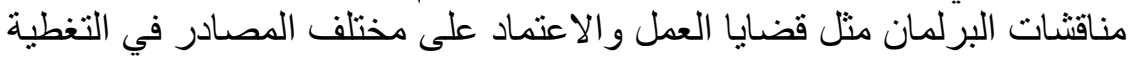

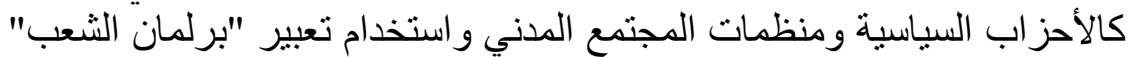

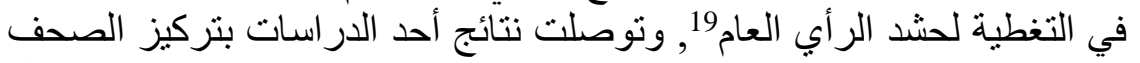

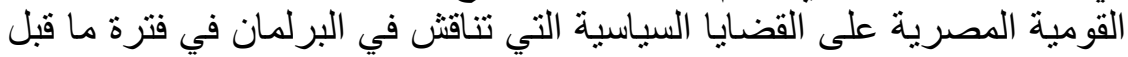

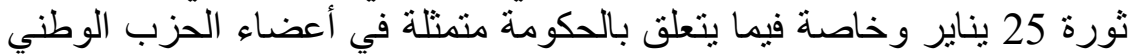

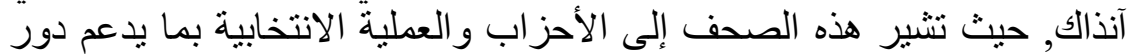

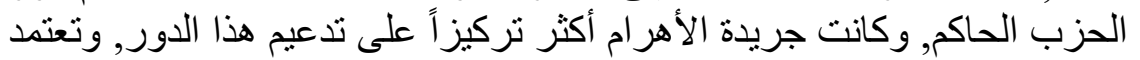

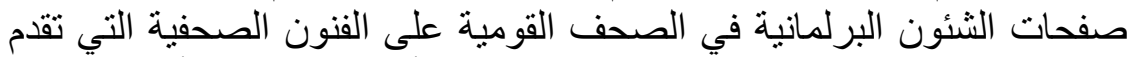

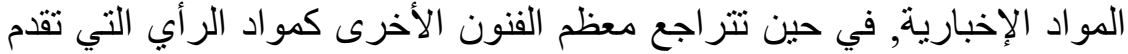

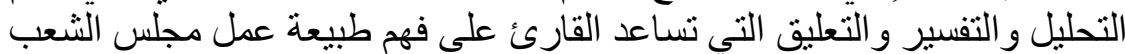

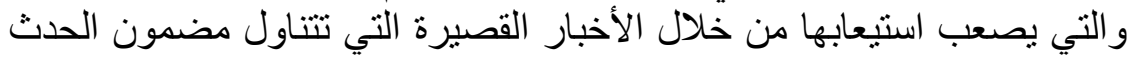

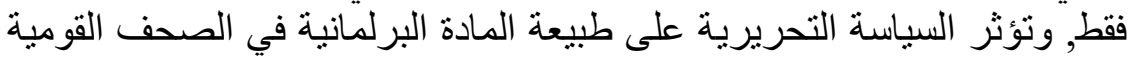

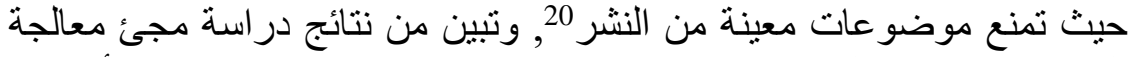

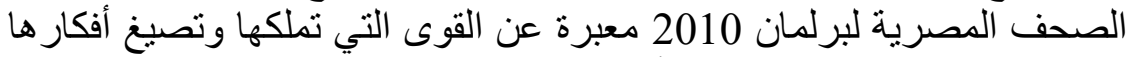

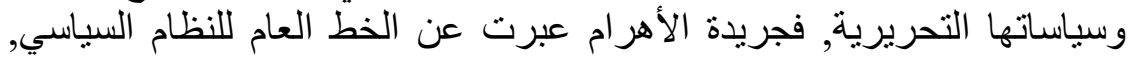

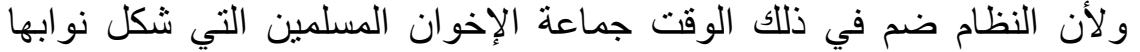

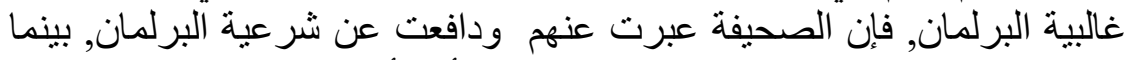

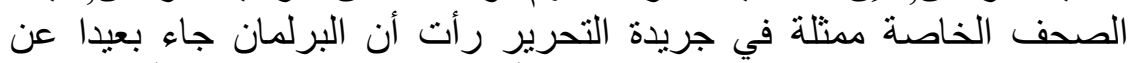

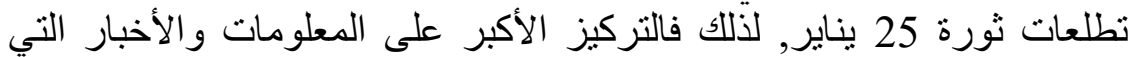

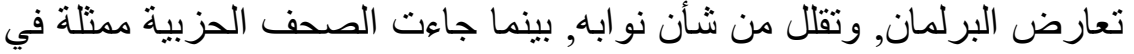

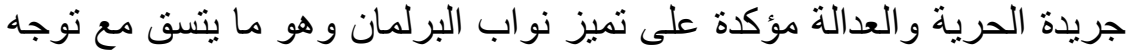

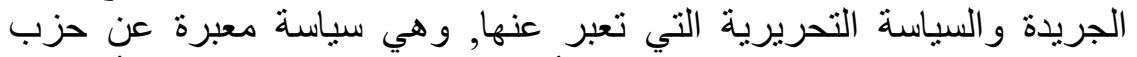

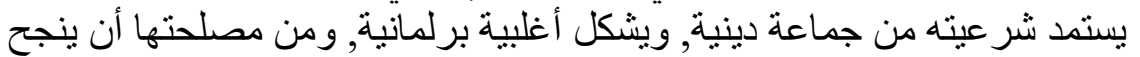

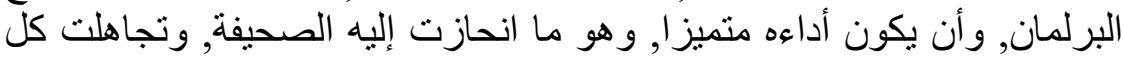

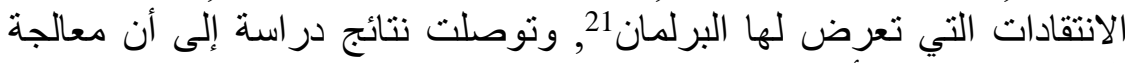

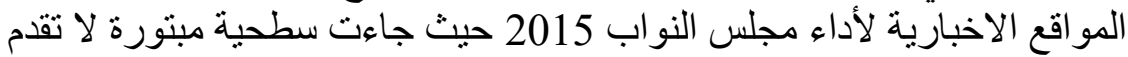
تحليلا وشرحا وتفسيرا لكثير من الأحداث، وجاءت معظم الأخبار قصيرة

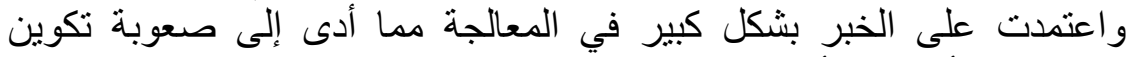

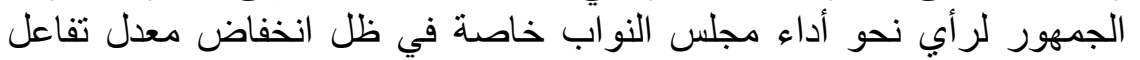

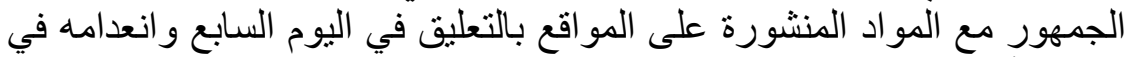
بوابة الأهر ام وموقع الوفد, كما لم تعكس المعالجة الإخبارية نمط الملكية حيث 
تشابهت المو اقع الإخبارية في معالجتها، و الأطر المستخدمة ووسائل التأطير ، ولم

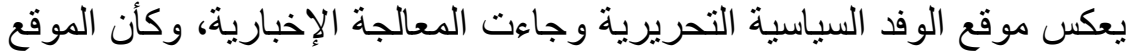

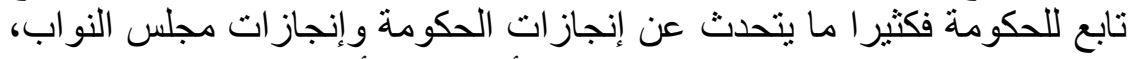

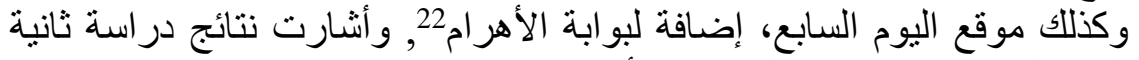

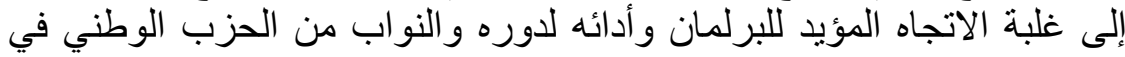

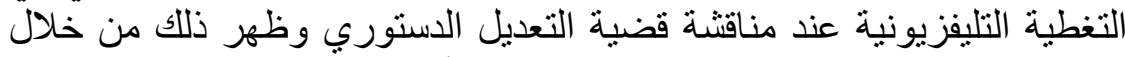

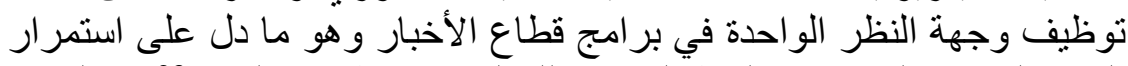

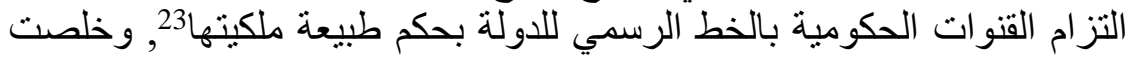

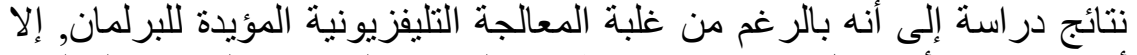

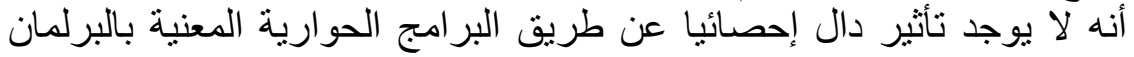

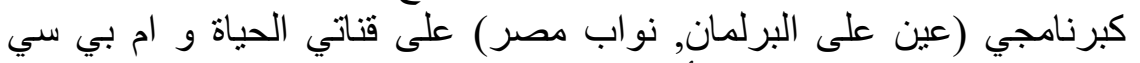

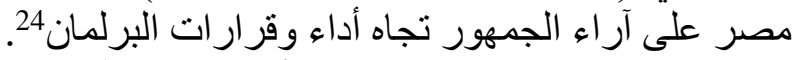

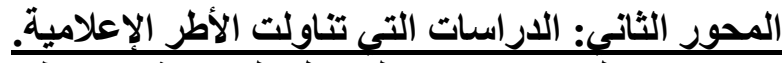

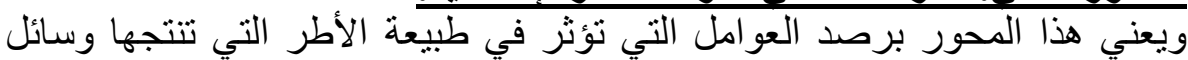

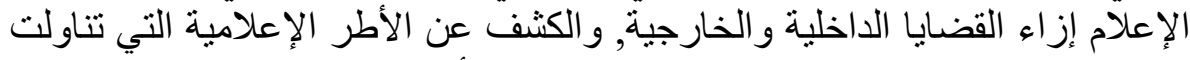

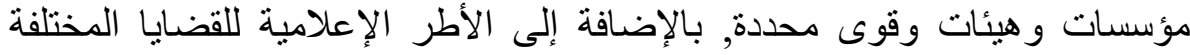

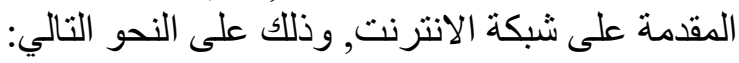

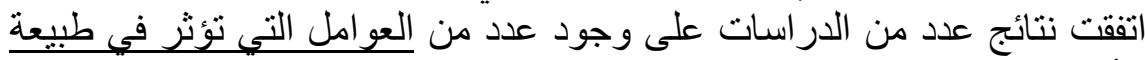

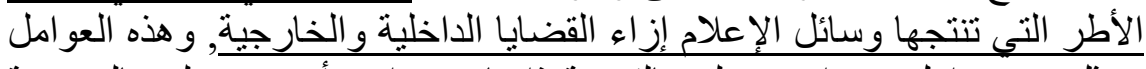

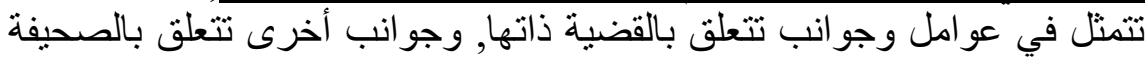

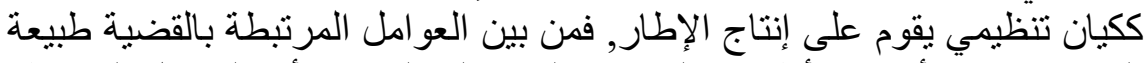

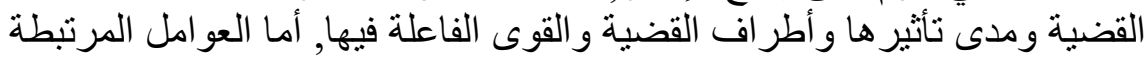

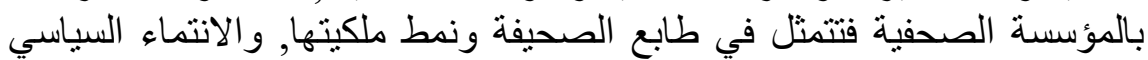

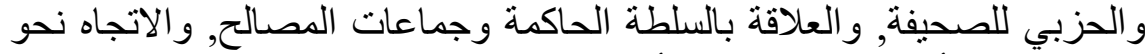

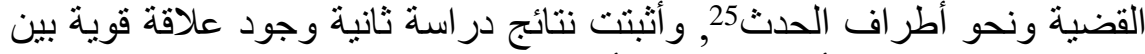

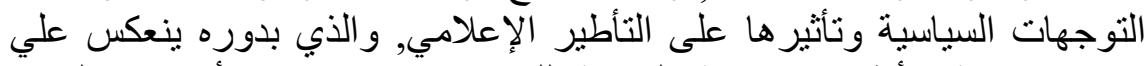

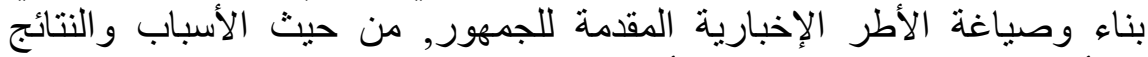

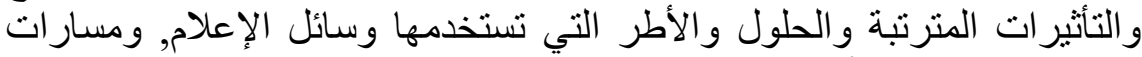

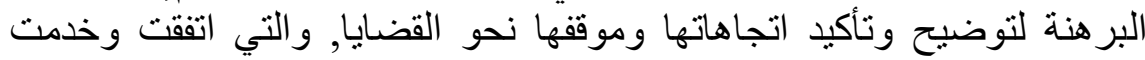

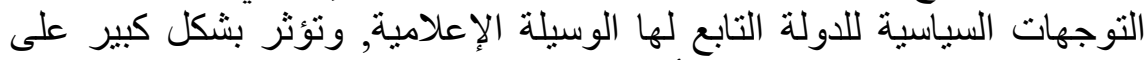

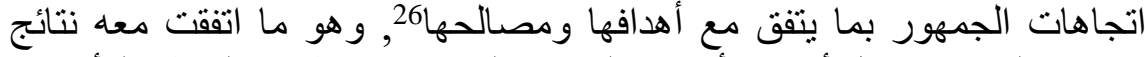

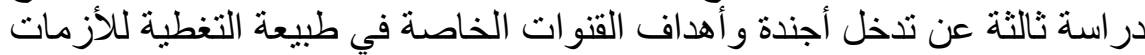

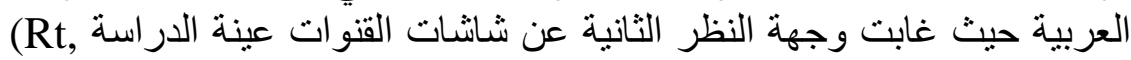

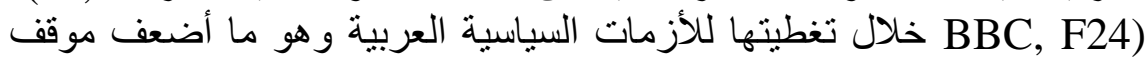

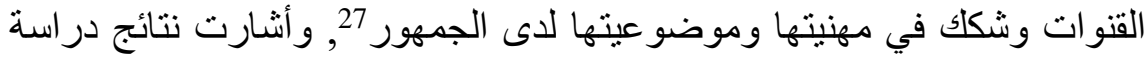


رابعة إلى إدرالك الجمهور أن تمويل القنوات الفضائية التليفزيونية له دور فيى الفي

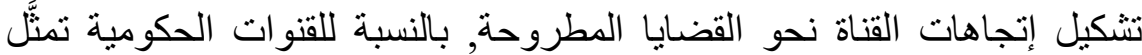
المجال الأبرز لتأثير التَّويل فى تحديد المحاور التى يتم مناقثتنها فى القضايا

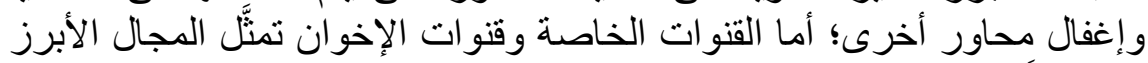

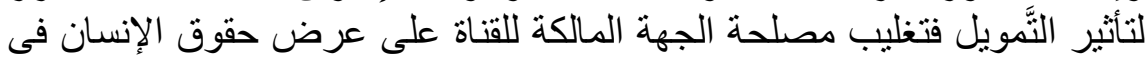

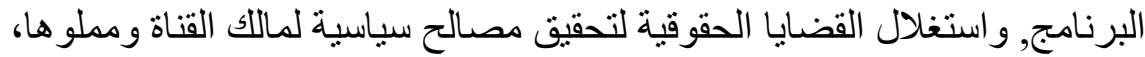
ورفض عرض وجهات النظر المعارضة لوجهة النظر التى تنتباها القناة،

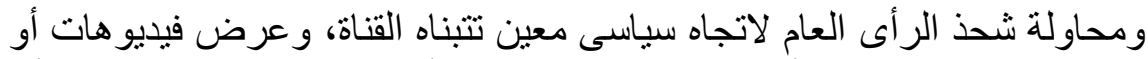

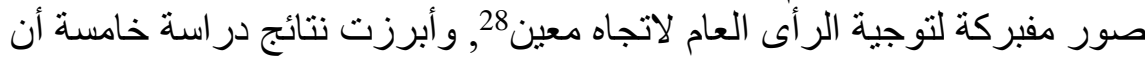

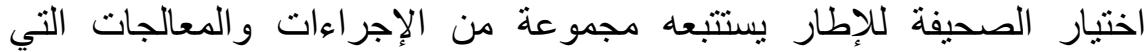

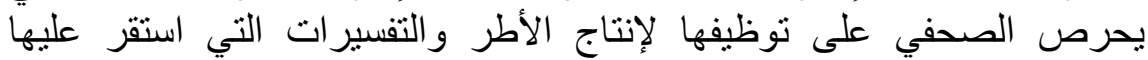
لمعالجة القضية, وتتمثل في زوايا المعالجة, وطبيعة المصاد الادر التي يتم الاعتماد

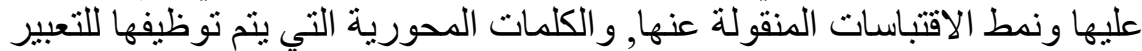

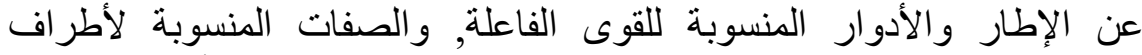

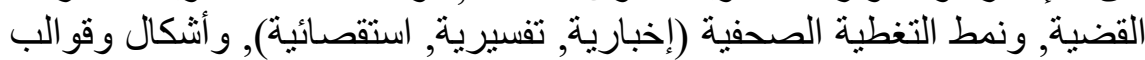

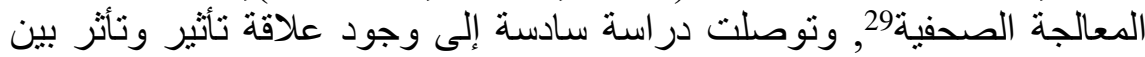
الأطر الفردية والأطر الإعلامية والسلطة السياسية الحاكمة حيث كانت التانة الأطر

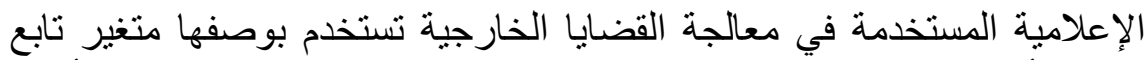

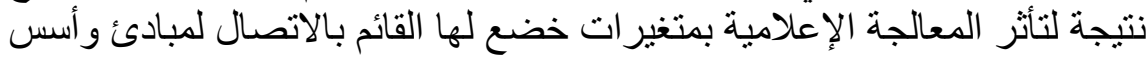
السياسة الإعلامية والتي ترتبط بقيود تنظيمية ونمط الملكية وقو اعد علاقتها

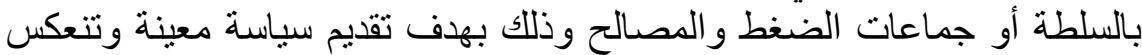

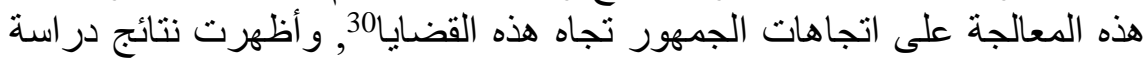

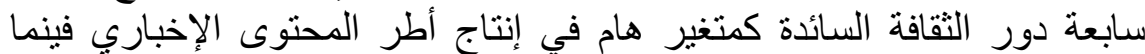

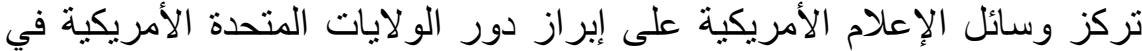

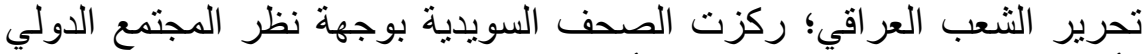

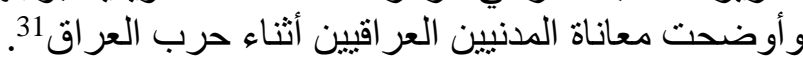

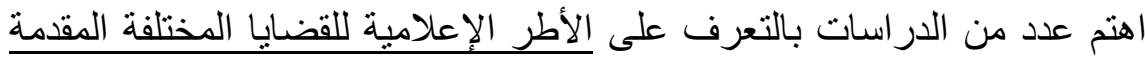

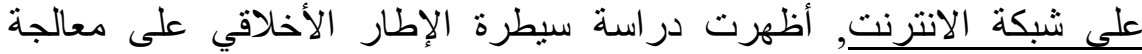

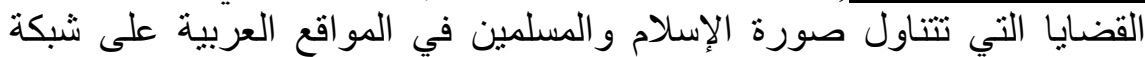

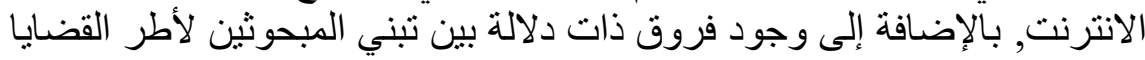

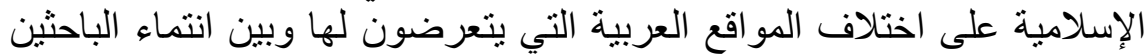

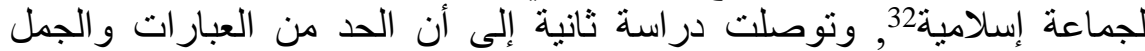

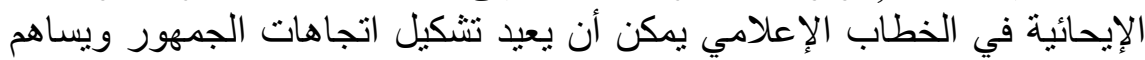
في تعديلها بشأن القضايا الثائكة المتعلقة بالأقليات أو القيد القضايا ذات أبات الطبيعة الدينية 
• اعتمد عدد كبير من الدر اسات على نظرية تحليل الإطار الإعلامي مدخلاً بحثياً لها,

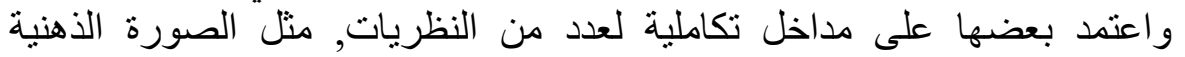

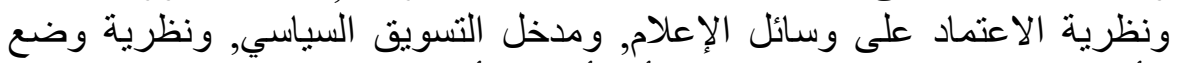

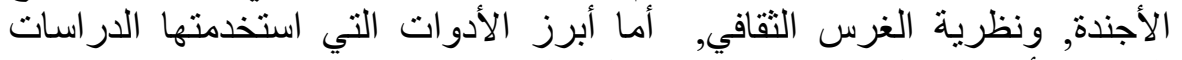

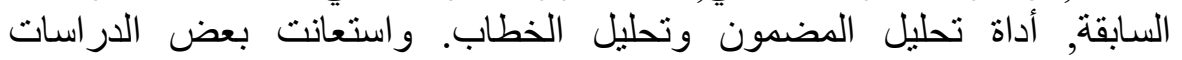

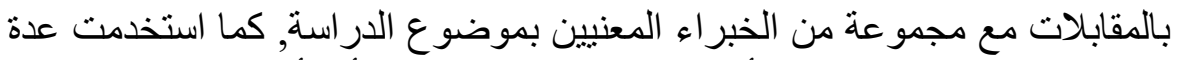

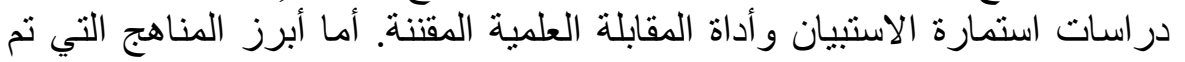

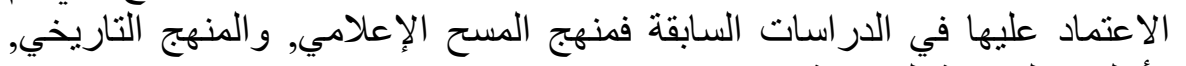

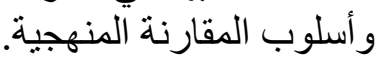

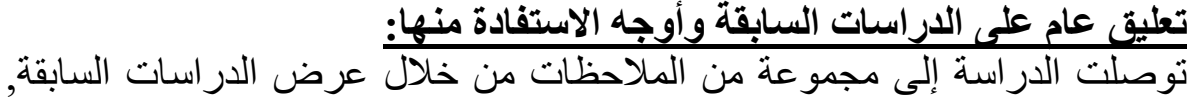

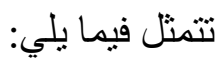

تنو عت الأطر التي استخدمتها الدراسات السابقة في معالجتها للأحداث أو القضايا

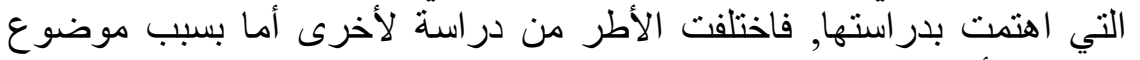

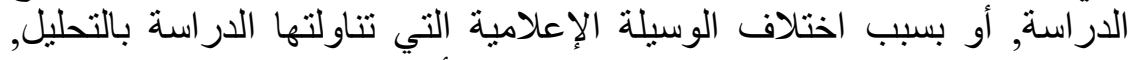

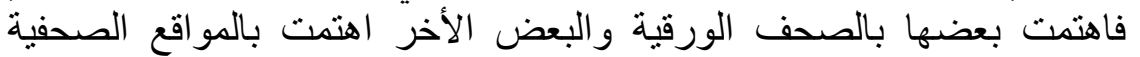

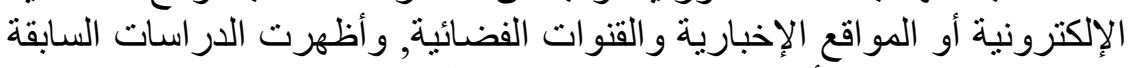

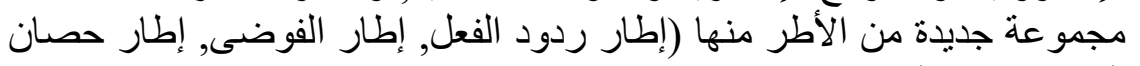

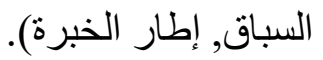

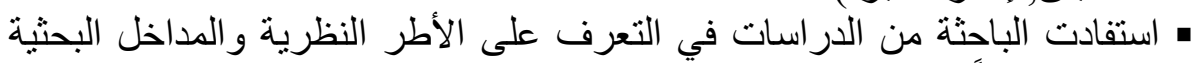

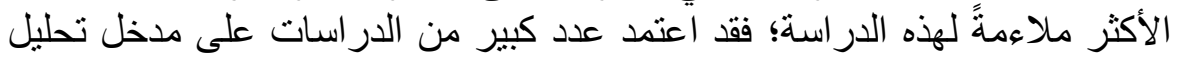

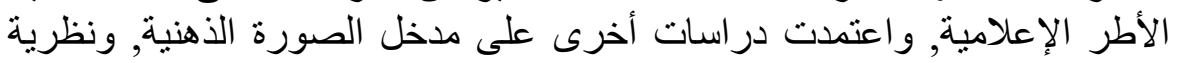

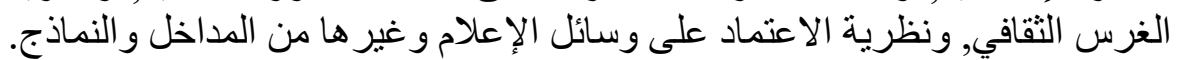

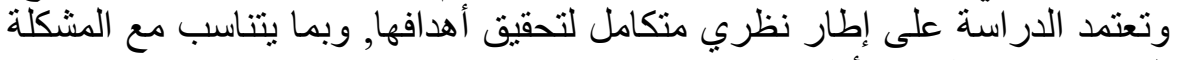
البحثية, وهو نظرية الأطر الإعلامية.

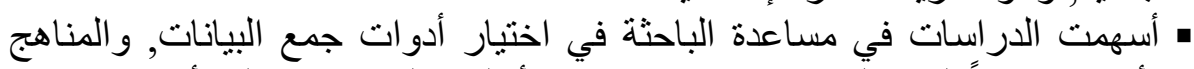

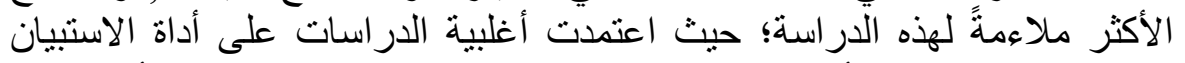

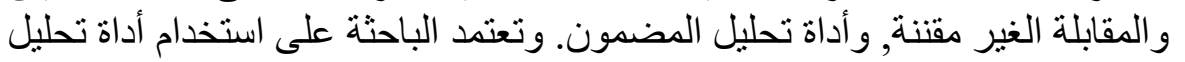

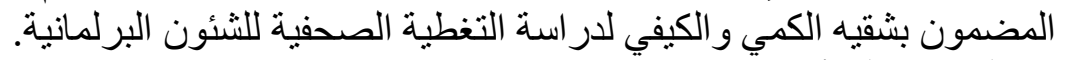

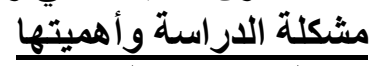

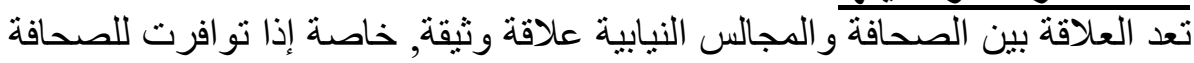

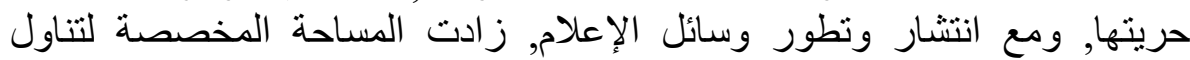

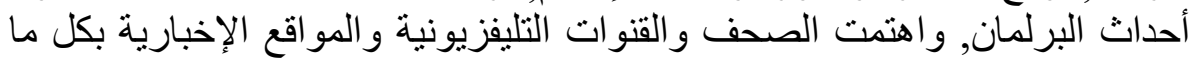

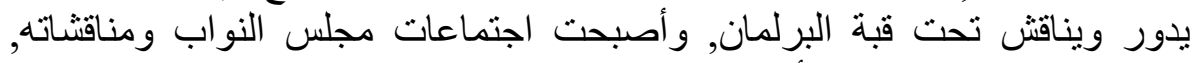
و القوانين التي يصدر ها, وأدواته الرقابية التي يستخدمها النواب في رقابة التيات السلطة 
التنفيذية في بؤرة اهتمام وسائل الإعلام عامة, و الصحف خاصةً, لأنها من الشئون

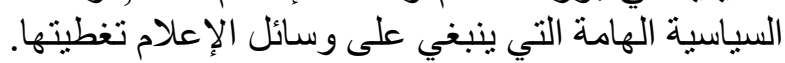

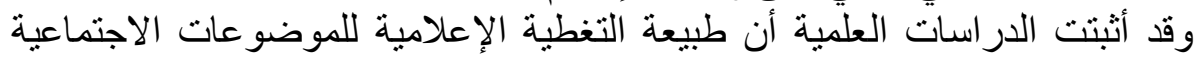

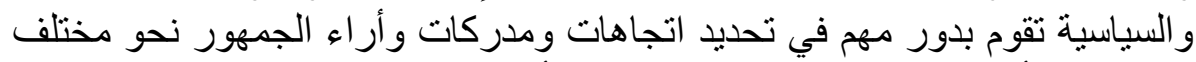

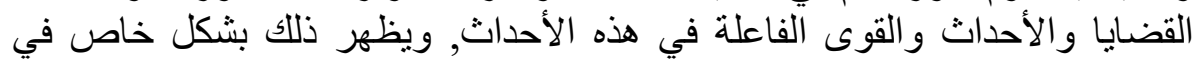

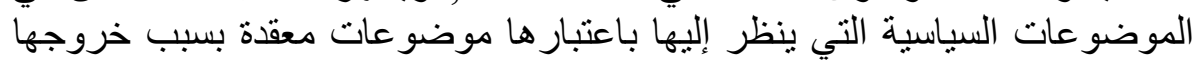

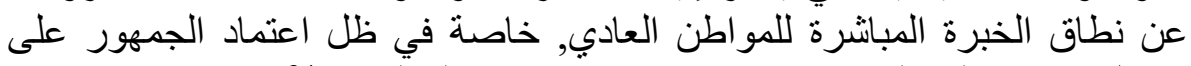

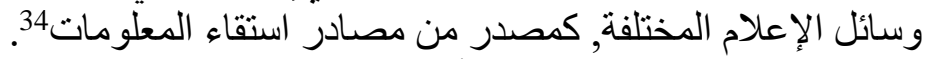

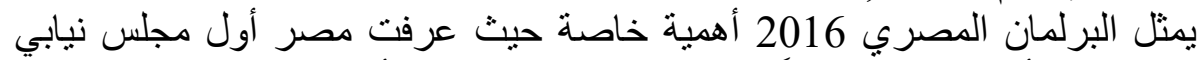

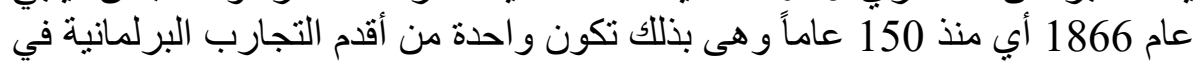
التاريخ المعاصر, وهو يعبر عن مرحلة ما بعد ثورني

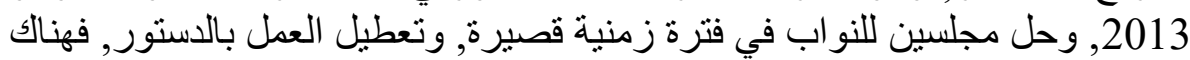

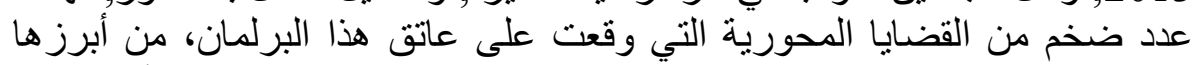

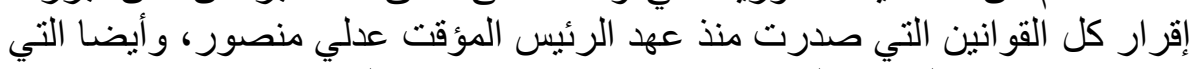

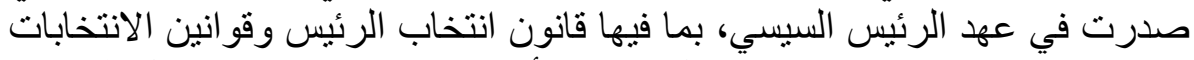

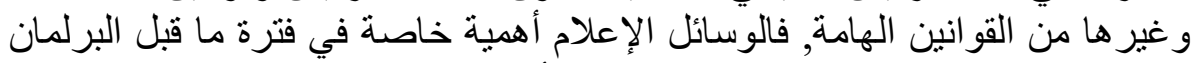

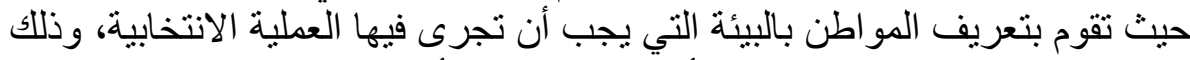

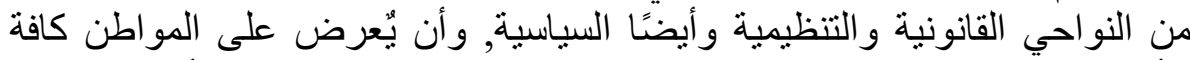

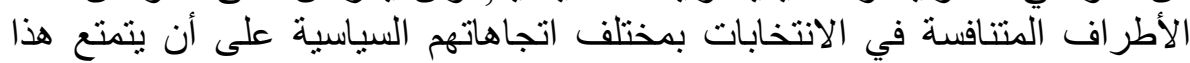

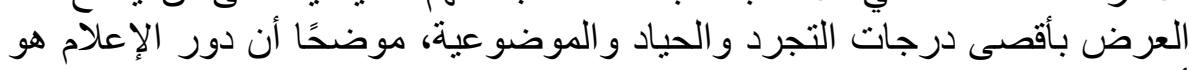

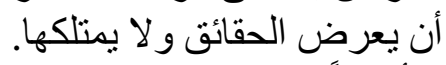

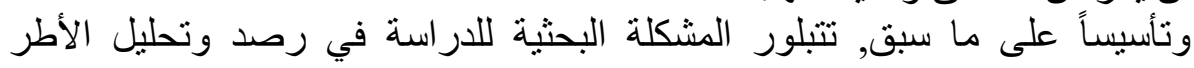
الإخبارية المستخدمة في تقديم برلمان

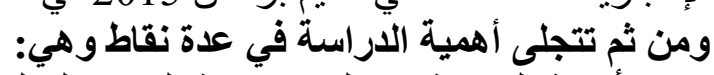

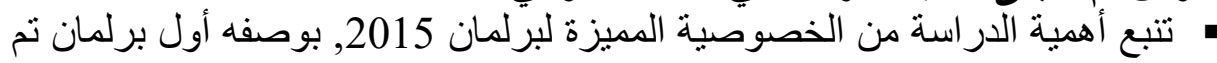

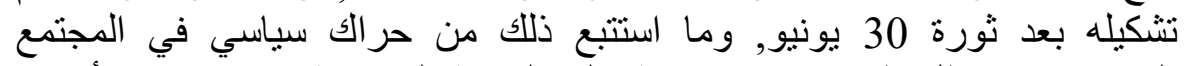

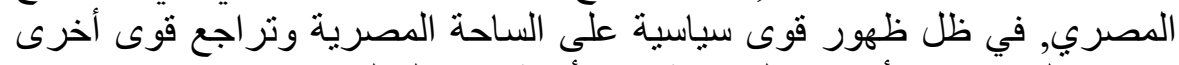

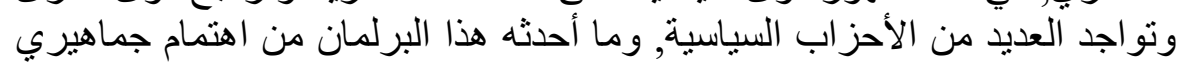

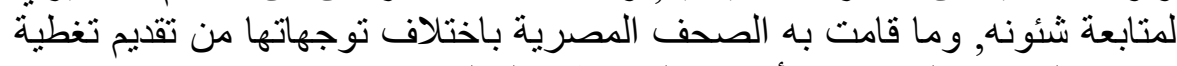

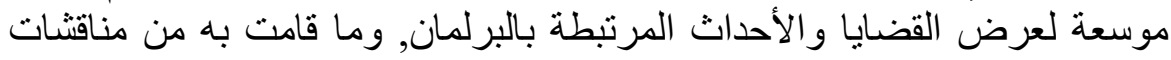
و متابعة لتطور اتها. ـ أهمية رصد الأطر التي يستخدمها القائم بالاتصال في الصحافة المصرية باختلاف والتهاف

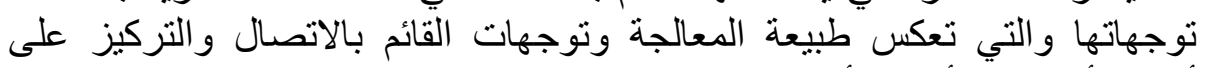
أحداث أو تجاهل أحداث ؤن أو تنميط مو اقف معينة. 


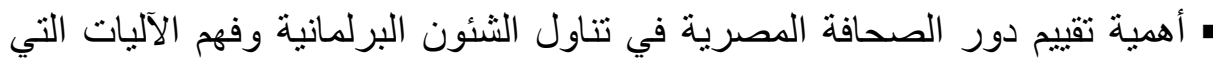

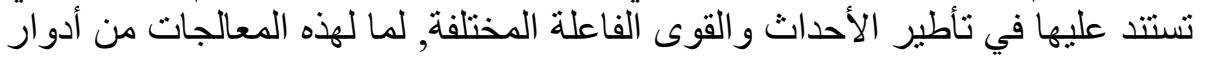

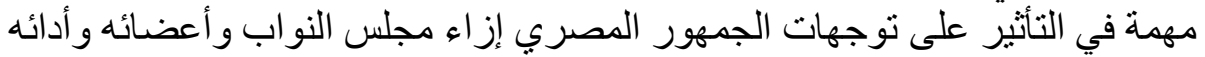

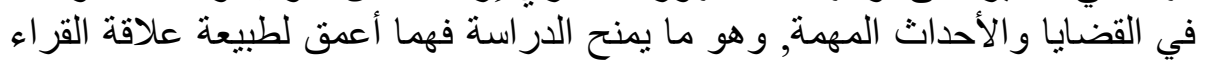

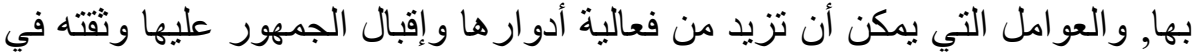
تغطيتها.

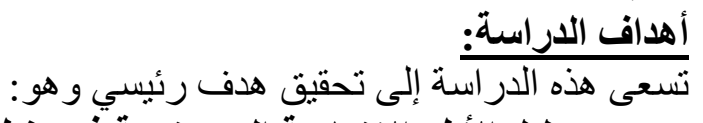

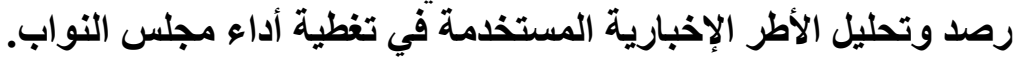

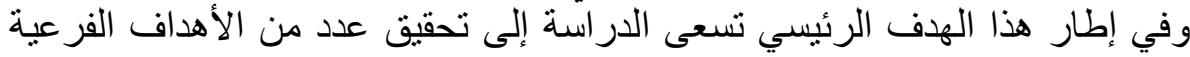

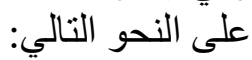

1- التعرف على مدى الاختلاف بين الصحف القومية و الحزبية والخاصة في تناولها الإخباري لمجلس النو اب, حيث إن تباين اتجاهاتها قد يؤدي بدوره إلى التى التركيز على التى

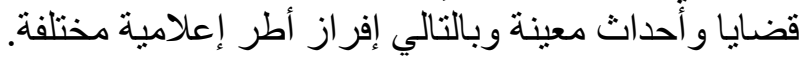

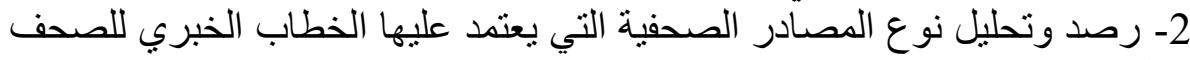

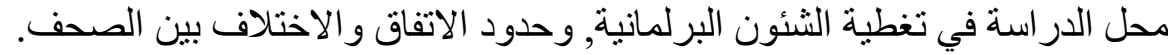

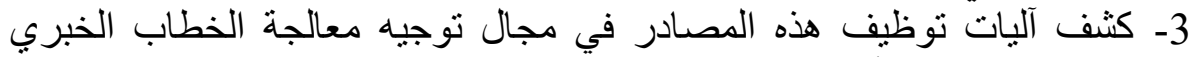
للشئون البرلمانية, ونأثيرات هذا التوظيف في بناء تحيزات التئ الخطاب الخبري في الصحف محل الدراسة. 4- تقييم الصحف المصرية لأداء مجلس النواب 2015. تساؤلات الار اسة الصة

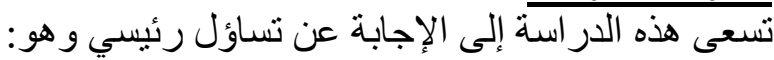

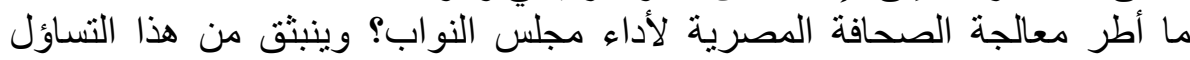

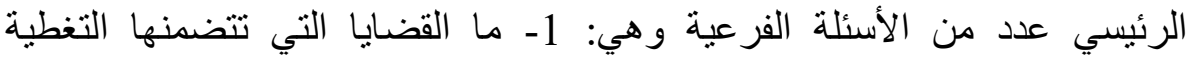

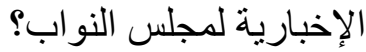

2- ما الأطر المسيطرة على الخطاب الخبري لصحف النح الدر اسة في تغطية الثنئون البرلمانية؟ 3- كيف قيمت الصحف المصرية أداء مجلس النو اب 2016 خلال دور الصات انعقاده ؟ الإطار المنهجى للاراسة نوع الأراسة: المنئ:

تتنمي هذه الدراسة إلى نوع الدراسات الوصفية التحليلية التفسيرية التي تعرف بأنها:

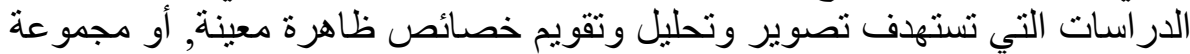

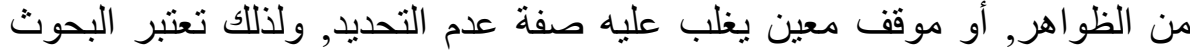

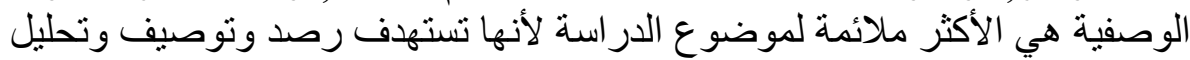

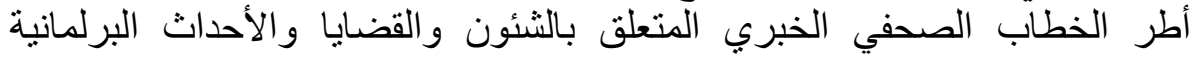
بالصحافة المصرية. 
منهج الدراسة

1- منهج المستح الإعلامى

تعتمد الدراسة على استخدام منهج المسح الإعلامي وتستخدمه الباحثة على النحو

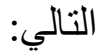

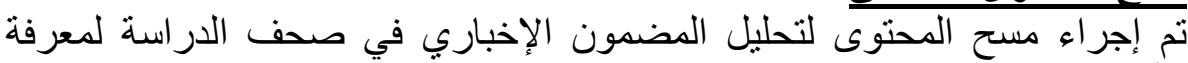

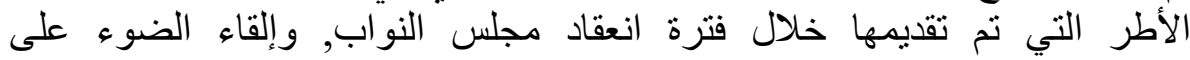

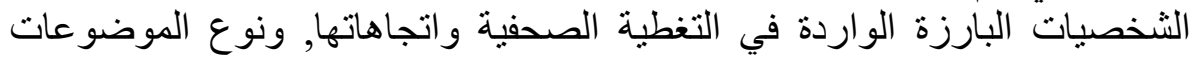

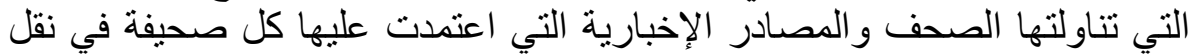

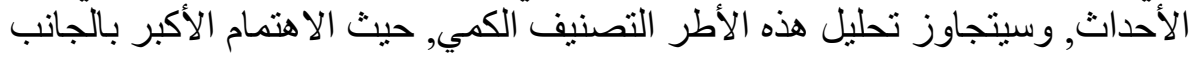

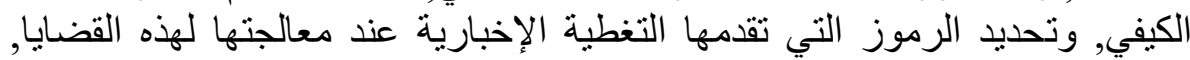

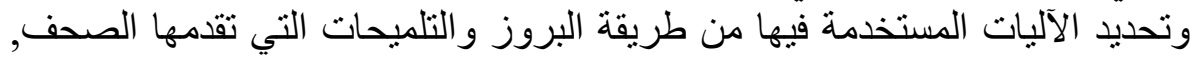

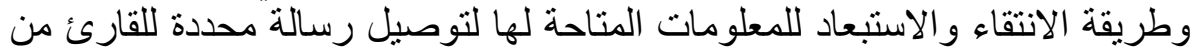

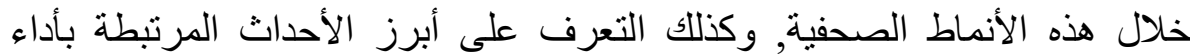

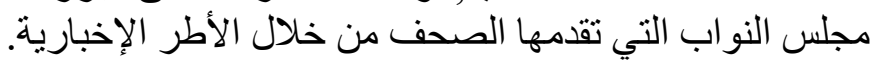
2- اسلوب المقارنة المنهجية المبالية تم استخدام المنهج المقارن لمعرفة المئة الفروق بين أطر التناول الإخباري لمجلس النواب

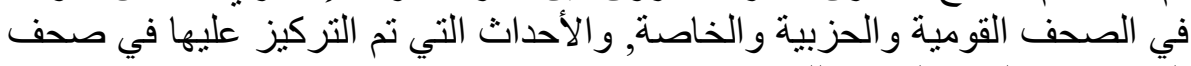
الدر اسة في الفترة الزمنية للعينة.

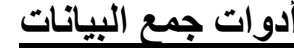

تعتمد الدراسة على مدخل تحليل الإطار الخبري, وذلك من خلال استخدام أداة:

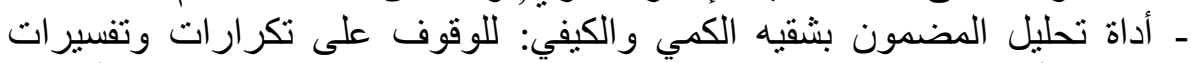

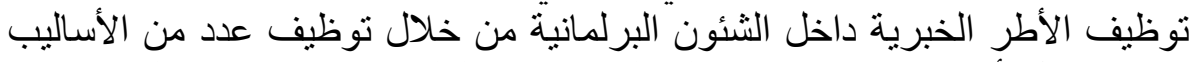

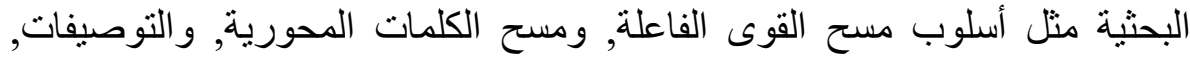
و العناوين الرئيسية والفرعية, ومسح مصادر التغطية.

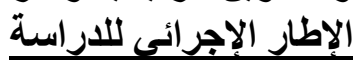

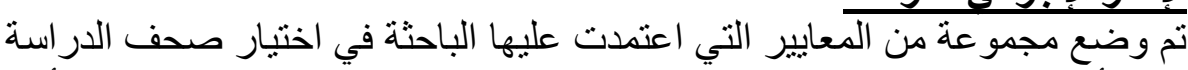

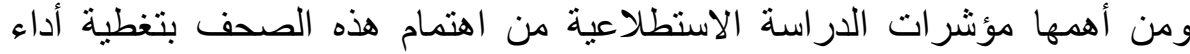

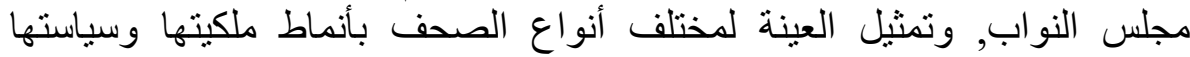

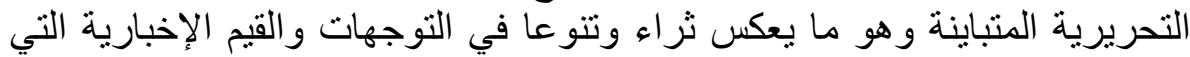

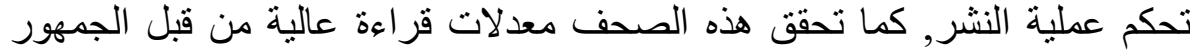

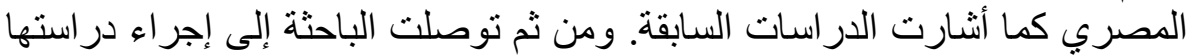

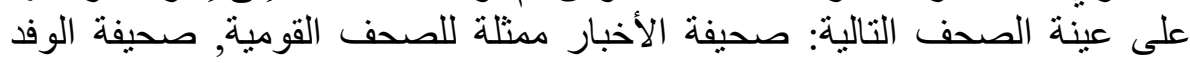
ممثلة للصحف الحزبية, صحيفة المصري اليوم ممثلة للصحف الخاصة. 
ـ العينة الموضوعية:

تشتمل الدراسة على در اسة كافة الأشكال الخبرية من "خبر وتقرير إخباري وقصة خبرية", التي اهتمت بالثئون البرلمانية كالنة الانية.

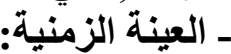

بدءا من أكتوبر 2017 حتى يوليونة 2018, ويرجع ذللك إلى أنه خلال هذه الفترة

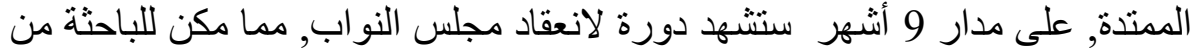

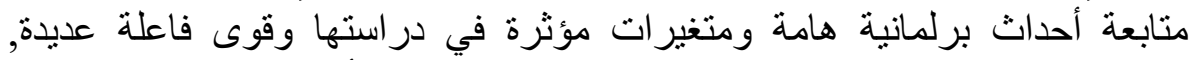

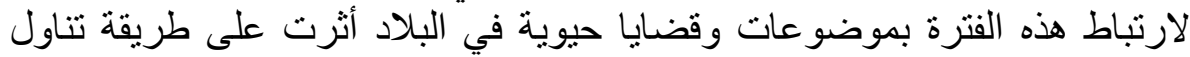

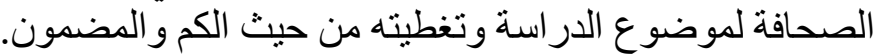

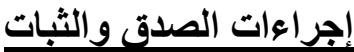

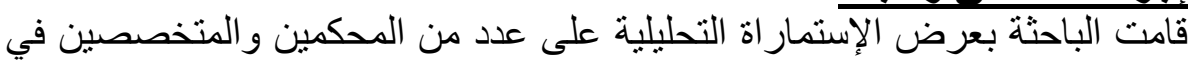

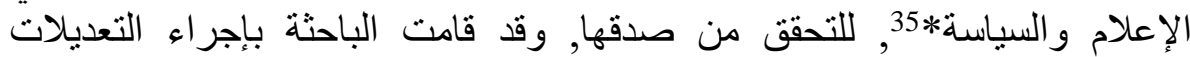

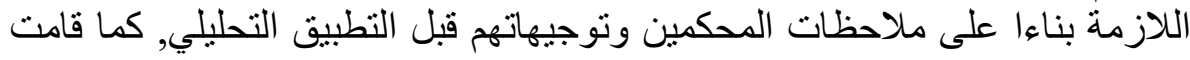

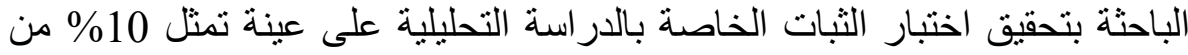

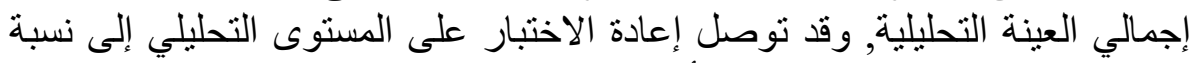

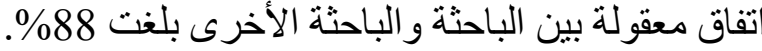

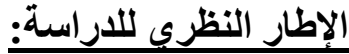

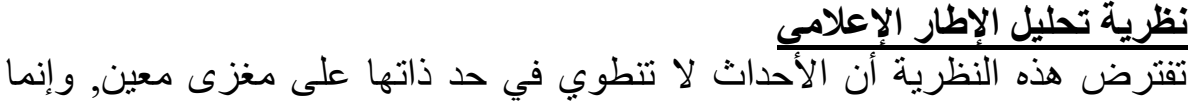

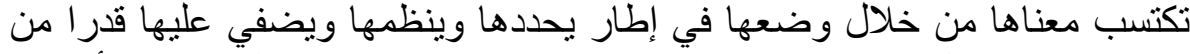

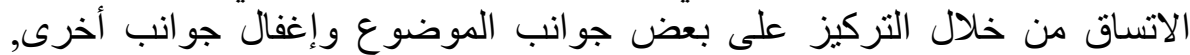

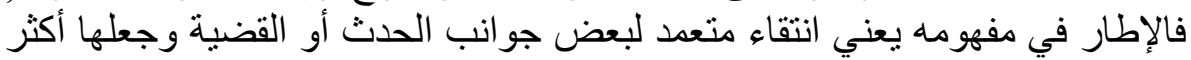

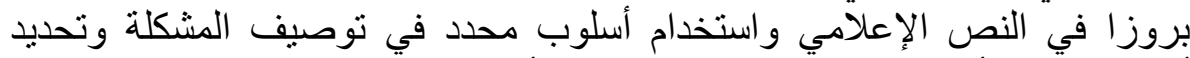

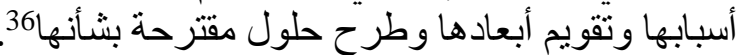
يعتمد قرار بناء إطار معين لقضية ونشرها وانيا بطريقة معينة على أسلوب السياسية

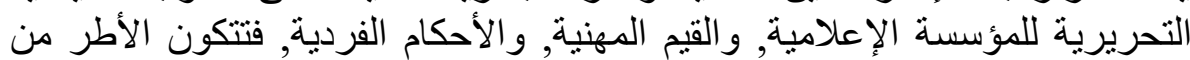

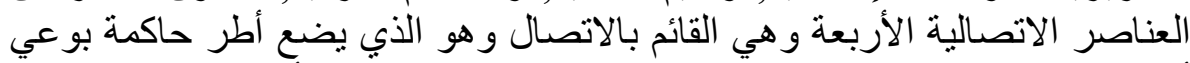

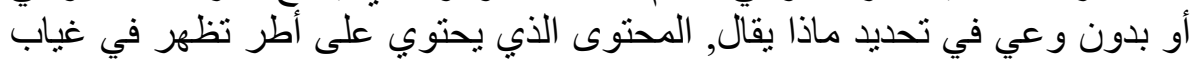

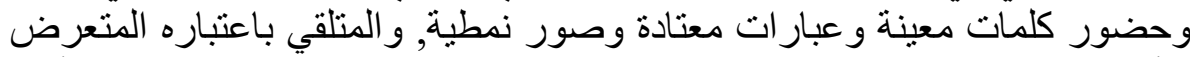

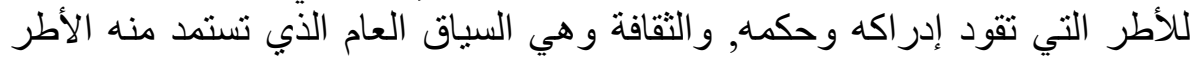

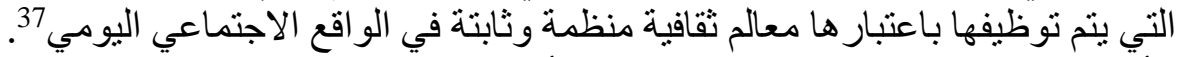

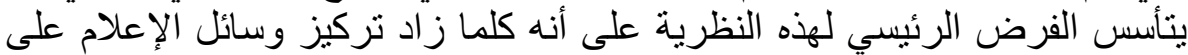

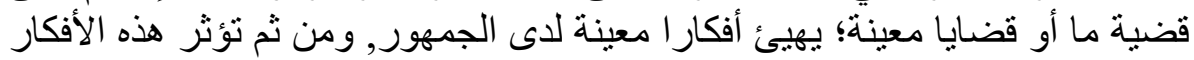

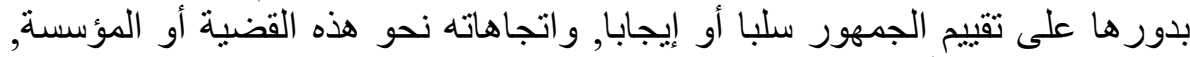
وما يرتبط بها من أحداث وقضايان. 
ستقوم الباحثة بدر اسة وتحليل الأشكال الخبرية التي قدمت أداء مجلس النواب خلال

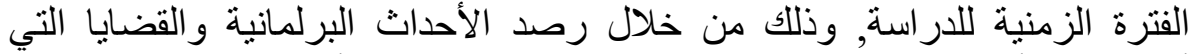

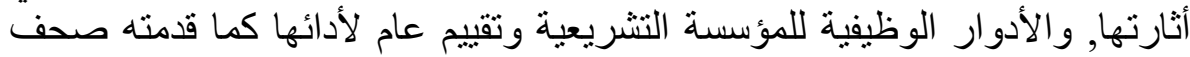

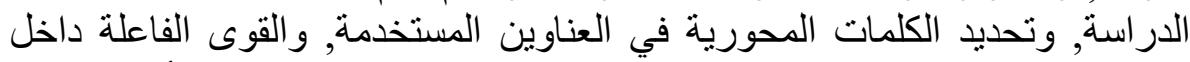

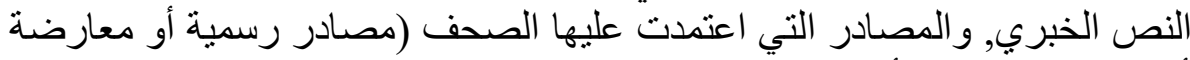

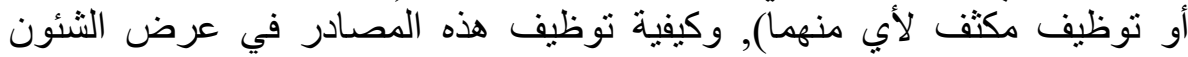

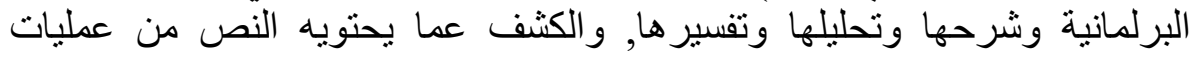

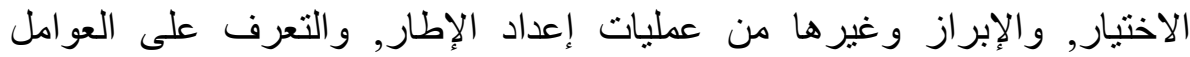

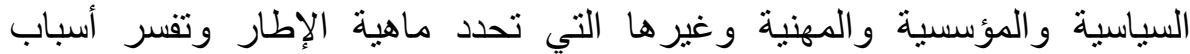

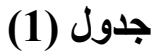

الأشكال الصحفية الصاية

الأشكال الصحفية المستخدمة في تغطية الشئون البرلمانية بصحف الدراسة

\begin{tabular}{|c|c|c|c|c|c|}
\hline الإجمالي & الوفد & المصري اليوم & الأخبار & & الشيكليفة \\
\hline 380 & 132 & 144 & 104 & 5 & \multirow{2}{*}{ تقرير إخباري } \\
\hline$\% 40.1$ & $\% 40.9$ & $\% 40.2$ & $\% 39$ & $\%$ & \\
\hline 295 & 56 & 126 & 113 & S & \multirow{2}{*}{ خبر قصير } \\
\hline$\% 31.1$ & $\% 17.3$ & $\% 35.2$ & $\% 42.3$ & $\%$ & \\
\hline 273 & 135 & 88 & 50 & S & \multirow{2}{*}{ قصة إخبارية } \\
\hline$\% 28.8$ & $\% 41.8$ & $\% 24.6$ & $\% 18.7$ & $\%$ & \\
\hline 948 & 323 & 358 & 267 & S & \multirow{2}{*}{ الإجمالي } \\
\hline$\% 100$ & $\% 100$ & $\% 100$ & $\% 100$ & $\%$ & \\
\hline
\end{tabular}

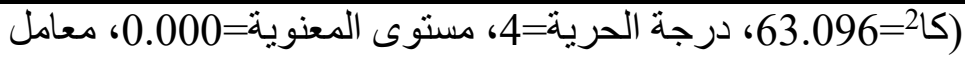

$$
\text { التو افق=0.250) }
$$

يوضح الجدول السابق الأشكال الصحفية الخبرية التي اعتمدت عليها صحف الدر اسة الته

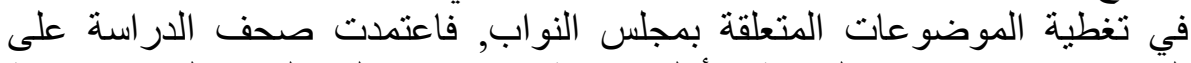

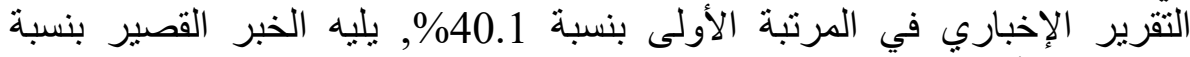
\%31.1, و أخيرا القصة الإخبارية بنسبة 28.8\%

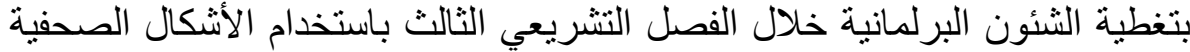

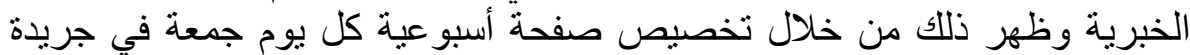

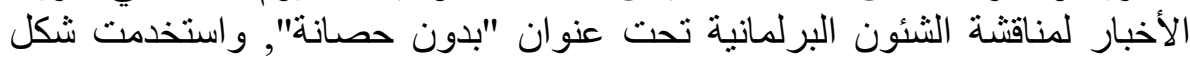

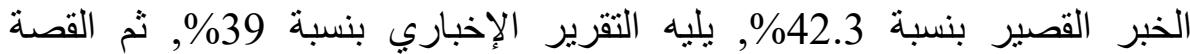

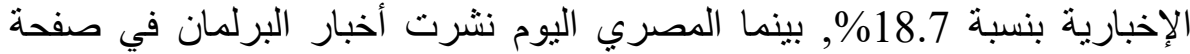

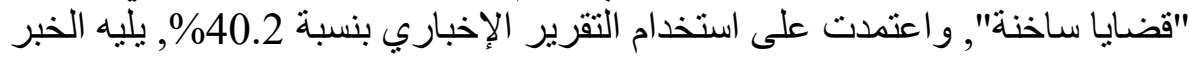

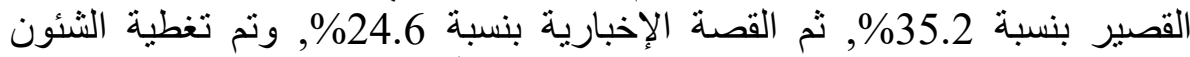
البرلمانية في جريدة الوفد في صفحة تحمل عنوان "أوراق برلمانية", و اعتمدت على 
استخدام القصة الإخبارية بنسبة 41.8\%, يليه التقرير الإخباري بنسبة 40.9\%, ثم

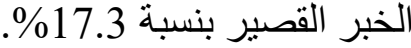

(2) جدول (2)

المصادر الصحفية

مصادر الموضوعات الصحفية بالصحف الثلاثة محل التحليل

\begin{tabular}{|c|c|c|c|c|c|}
\hline الإجمالي & الوف & المصري اليوم & الأخبار & \multirow{3}{*}{\multicolumn{2}{|c|}{$\begin{array}{l}5 \\
\%\end{array}$}} \\
\hline 891 & 316 & 358 & 217 & & \\
\hline$\% 94$ & $\% 97.8$ & $\% 100$ & $\% 81.3$ & & \\
\hline 53 & 6 & - & 47 & 5 & \multirow[b]{2}{*}{ بلدون مصدر } \\
\hline$\% 5.6$ & $\% 1.9$ & - & $\% 17.6$ & $\%$ & \\
\hline 2 & - & - & 2 & 5 & \multirow{2}{*}{ وكالة أنباء } \\
\hline$\% 0.2$ & - & - & $\% 0.7$ & $\%$ & \\
\hline 2 & 1 & - & 1 & 5 & \multirow{2}{*}{ فضائيات } \\
\hline$\% 0.2$ & $\% 0.3$ & - & $\% 0.4$ & $\%$ & \\
\hline 948 & 323 & 358 & 267 & s & \multirow{2}{*}{ الإجمالي } \\
\hline$\% 100$ & $\% 100$ & $\% 100$ & $\% 100$ & $\%$ & \\
\hline
\end{tabular}

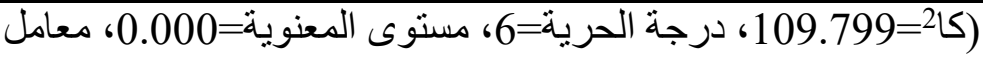

التو افق=0.322)

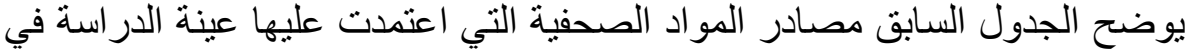

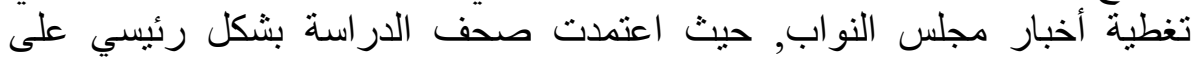

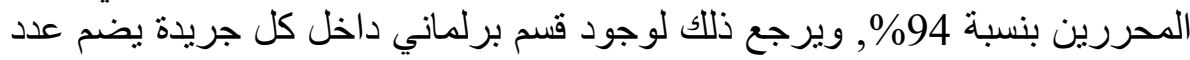

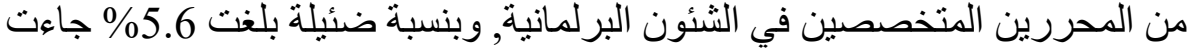
بعض الموضو عات مجهولة المصدر.

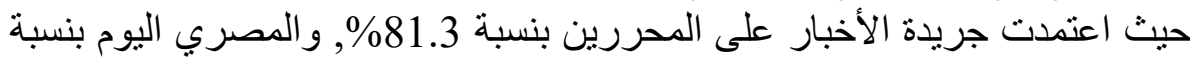
100\%, والوفد بنسبة 97.8\% لتشكل المصدر الرئيسي للمعلومات في الصحف الصف الثلاث.

(3) جدول (3) (ل)

مصادر الموضوع الصحفي المصادر الرسمية وغير الرسمية للمادة الصحفية بالصحف الثلاثة محل التحليل

\begin{tabular}{|c|c|c|c|c|c|}
\hline $\begin{array}{c}\text { (ن=الاجمالئ) } \\
\text { (948) }\end{array}$ & 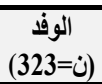 & النصري اليوم & $\begin{array}{c}\text { (نأَخبار) } \\
\text { (267) }\end{array}$ & & مصادر الموضيفو \\
\hline 781 & 295 & 277 & 209 & 4 & \multirow{2}{*}{ مصادر رسمية * } \\
\hline$\% 56.5$ & $\% 37.8$ & $\% 35.5$ & $\% 26.7$ & $\%$ & \\
\hline 599 & 211 & 236 & 152 & 5 & \multirow{2}{*}{ مصادر غير رسمية } \\
\hline$\% 43.5$ & $\% 35.5$ & 39.3 & $\% 25.3$ & $\%$ & \\
\hline
\end{tabular}

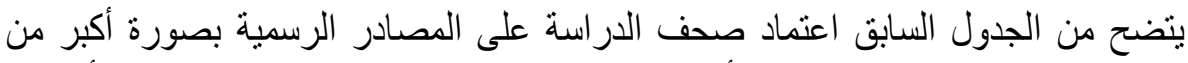

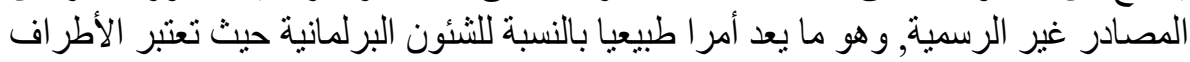




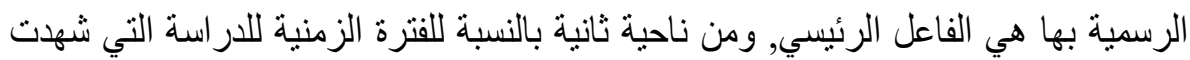

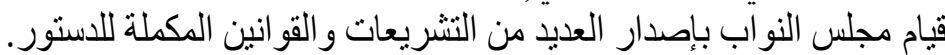

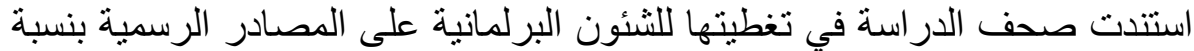

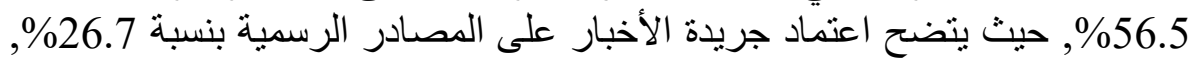

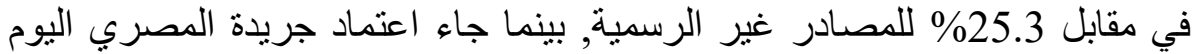

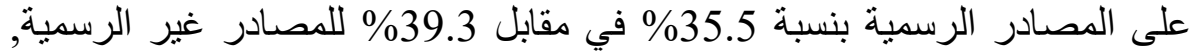

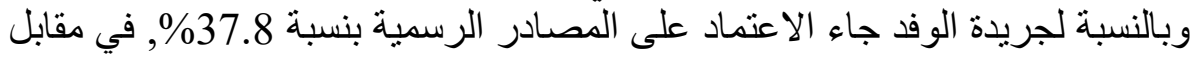
\%35.5

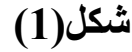

اختصاصات مجلس النواب

\section{قضايا مجلس النواب الواردة بالصحف الثلاثة محل الاراسة}

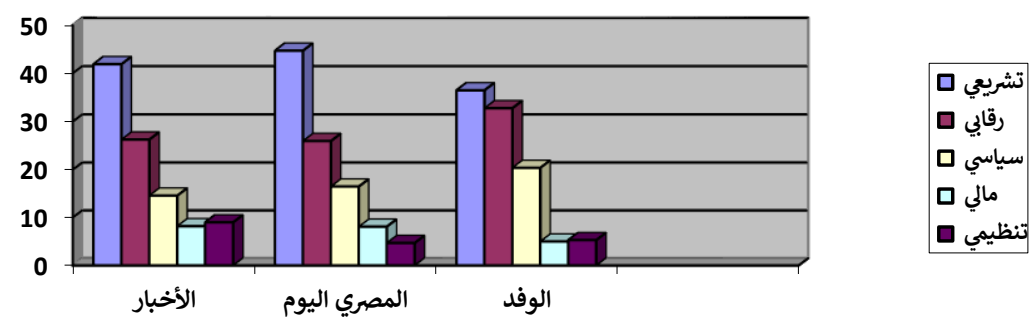

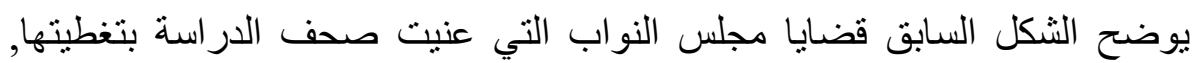

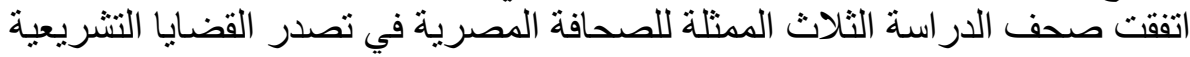

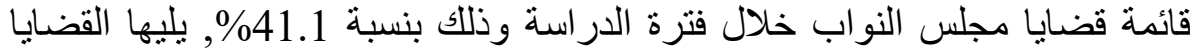

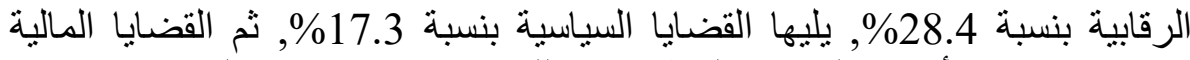

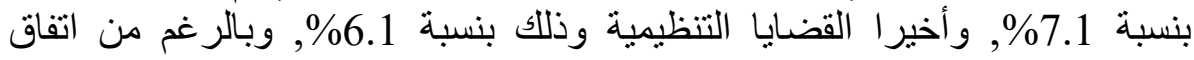
صحف الدراسة في معدل الاهتمام بالقضايا لكن اختلفت نوعية هذه القضائ القايا وطريقة

تناو لها وفقا لتوجهات كل جريدة و السياسة التحريرية الخاصة التها بها.

نوع الأطر المستخدمة لتوحات

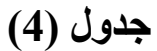

نوع الأطر الصحفية المستخدمة بالصحف الثلاثة محل التحليل

\begin{tabular}{|c|c|c|c|c|c|}
\hline الإجمالي & الوفد & المصري اليوم & الأخبار & \multirow{3}{*}{\multicolumn{2}{|c|}{ نوع الإطارة }} \\
\hline 95 & 23 & 27 & 45 & & \\
\hline$\% 10$ & $\% 7.1$ & $\% 7.5$ & $\% 16.9$ & & \\
\hline 853 & 300 & 331 & 222 & S & \multirow{2}{*}{ محدد } \\
\hline$\%$ & $\% 92.9$ & $\% 92.5$ & $\% 83.1$ & $\%$ & \\
\hline 948 & 323 & 358 & 267 & 5 & \multirow{2}{*}{ الإجمالي } \\
\hline$\% 100$ & $\% 100$ & $\% 100$ & $\% 100$ & $\%$ & \\
\hline
\end{tabular}

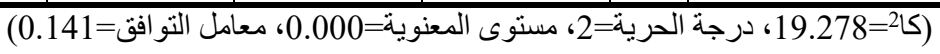




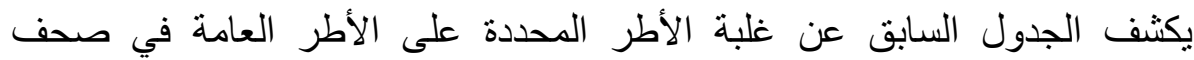

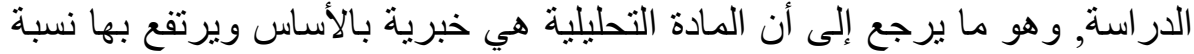

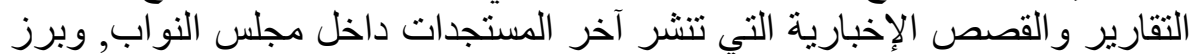

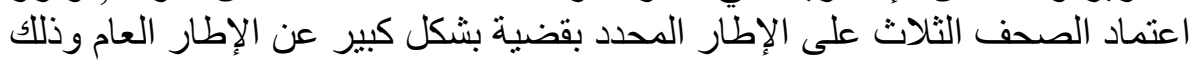

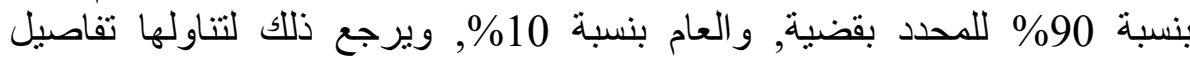

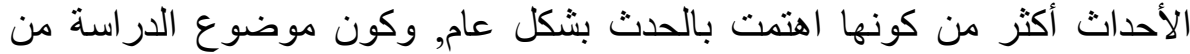

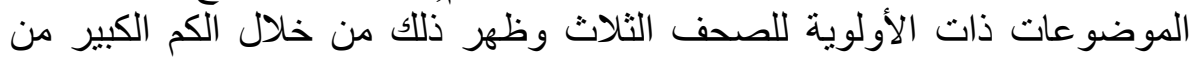

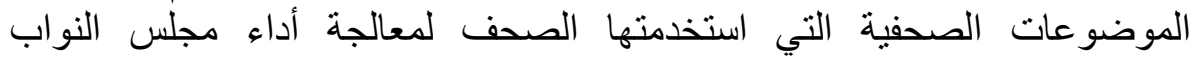

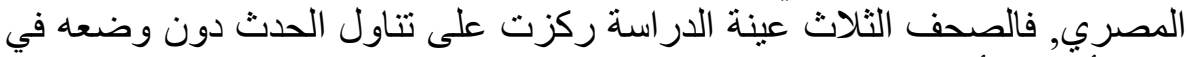
سياق أثنمل وأعمق, وتتفق هذه النتيجة مع نتائج دراسة إبر اهيم التوامج

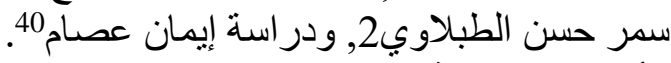

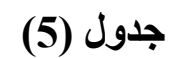

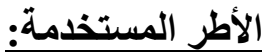

الأطر المستخدمة في تغطية الثئون البرلمانية بصحف الاراسة

\begin{tabular}{|c|c|c|c|c|c|c|}
\hline الإجمالي & الوفد & اليوري & الأخبار ال & & الأطر الفريفية & الأطر الرئيسية \\
\hline \multirow{3}{*}{408} & 81 & 63 & 83 & 9 & \multirow{2}{*}{ الاور التشريعي للمجلس } & \multirow{6}{*}{ المسئولية } \\
\hline & $\% 25.1$ & $\% 17.6$ & $\% 31.1$ & $\%$ & & \\
\hline & 56 & 59 & 31 & ك & \multirow{2}{*}{ الاور الرقابي للمجلس } & \\
\hline \multirow{3}{*}{$\% 43$} & $\% 17.3$ & $\% 16.5$ & $\% 11.6$ & $\%$ & & \\
\hline & 9 & 10 & 16 & ك & 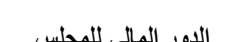 & \\
\hline & $\% 2.8$ & $\% 2.8$ & $\% 6$ & $\%$ & جبس & \\
\hline \multirow{4}{*}{110} & 20 & 37 & 13 & S & من & \multirow{6}{*}{ الصراع } \\
\hline & $\% 6.2$ & $\% 10.3$ & $\% 4.8$ & $\%$ & بيل المواب والحقوم & \\
\hline & 11 & 5 & 7 & ك & - & \\
\hline & \%3.4 & $\% 1.4$ & $\% 2.6$ & $\%$ & & \\
\hline \multirow{2}{*}{$\% 11.6$} & 6 & 7 & 4 & S & \multirow{2}{*}{ بين النواب ورئيس المجلس } & \\
\hline & $\% 1.8$ & $\% 1.9$ & $\% 1.5$ & $\%$ & & \\
\hline \multirow[t]{2}{*}{152} & 39 & 43 & 32 & (3) & \multirow{2}{*}{ شئون داخلية } & \multirow{4}{*}{ سياسي } \\
\hline & $\% 12$ & $\% 12$ & $\% 12$ & $\%$ & & \\
\hline \multirow{2}{*}{$\% 16$} & 13 & 17 & 8 & ك & \multirow{2}{*}{ شئون خارجية } & \\
\hline & $\% 4$ & $\% 4.7$ & $\% 3$ & $\%$ & & \\
\hline \multirow{5}{*}{130} & 11 & 10 & 17 & ك & \multirow{2}{*}{ لممارسات النواب } & \multirow{8}{*}{ النقا } \\
\hline & $\% 3.4$ & $\% 2.8$ & $\% 6.4$ & $\%$ & & \\
\hline & 24 & 18 & 7 & ك & لكما سيات الحكمية & \\
\hline & $\% 7.4$ & $\% 5$ & $\% 2.6$ & $\%$ & 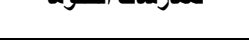 & \\
\hline & 3 & 28 & 6 & s & \multirow{2}{*}{ لأعمال المجلس } & \\
\hline \multirow{3}{*}{$\% 14$} & $\% 0.9$ & $\% 7.8$ & $\% 2.2$ & $\%$ & & \\
\hline & - & 6 & - & 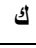 & \multirow{2}{*}{ لممارسات رئيس المجلس } & \\
\hline & - & 1.7 & - & $\%$ & & \\
\hline
\end{tabular}


أطر معالجة الصحف المصرية لأداء مجلس النواب 2015

\begin{tabular}{|c|c|c|c|c|c|c|}
\hline الإجمالي & الوفد & اليوري & الأخبار & & الأطر الفريفة & الأطر الرئيسيفية \\
\hline \multirow{5}{*}{67} & 11 & 15 & 14 & ك & & \multirow{8}{*}{ الإثارة و السخرية } \\
\hline & \%3.4 & $\% 4.2$ & $\% 5.2$ & $\%$ & ممارسات اللواب & \\
\hline & 8 & 7 & 4 & S & أعمال الحكو مة & \\
\hline & $\% 2.5$ & $\% 2$ & $\% 1.5$ & $\%$ & أعمال الحتومة & \\
\hline & - & 4 & - & S & & \\
\hline \multirow{3}{*}{$\% 7.1$} & - & $\% 1.1$ & - & $\%$ & قرارات المجلس & \\
\hline & - & 4 & - & S & & \\
\hline & - & $\% 1.1$ & - & $\%$ & رئيس المجلس & \\
\hline 37 & 18 & 10 & 9 & 5 & & \multirow{2}{*}{ ابراز الايجابيات } \\
\hline$\% 3.9$ & $\% 5.5$ & $\% 2.8$ & \%3.3 & $\%$ & & \\
\hline 16 & 3 & 4 & 9 & S & \multirow[b]{2}{*}{ - } & \multirow{2}{*}{ اقتصادي } \\
\hline$\% 1.7$ & $\% 0.9$ & $\% 1.1$ & \%3.4 & $\%$ & & \\
\hline 28 & 10 & 11 & 7 & S & \multirow[b]{2}{*}{ - } & \multirow{3}{*}{ التبرير والتعليل } \\
\hline$\% 3$ & $\% 3.1$ & $\% 3.1$ & $\% 2.6$ & $\%$ & & \\
\hline 948 & 323 & 358 & 267 & S & \multirow{2}{*}{ الإجمالي } & \\
\hline$\% 100$ & $\% 100$ & $\% 100$ & $\% 100$ & $\%$ & & \\
\hline
\end{tabular}

يوضح الجدول السابق الأطر الصحفية المستخدمة في تغطية الثئون البرلمانية

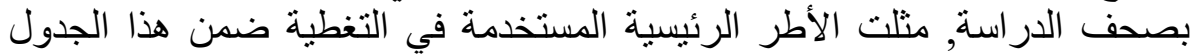

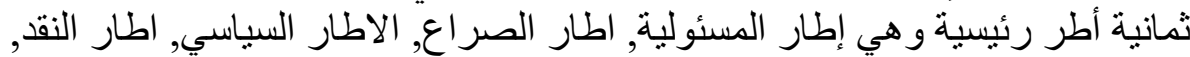

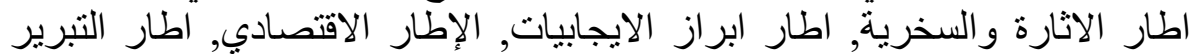

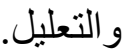
وتم تقسيم الأطر الرئيسية بدورها إلى مجموعة من الأطر الفرعية الأكثر توضيحا

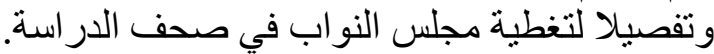

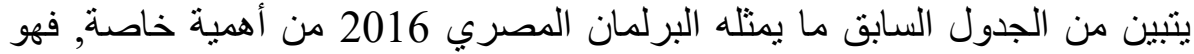

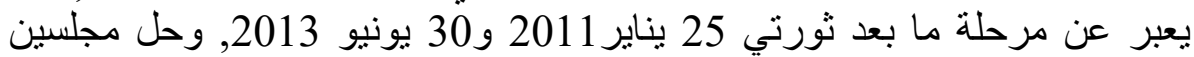

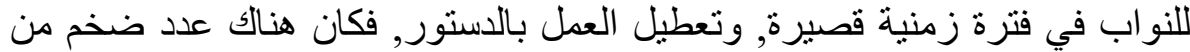

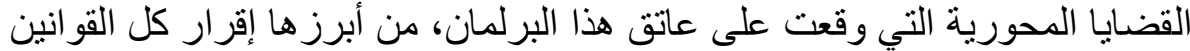

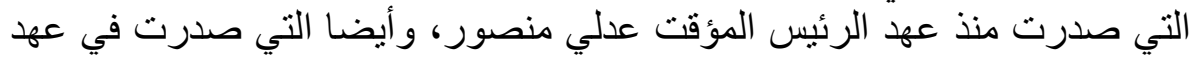

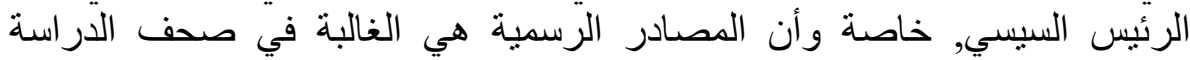

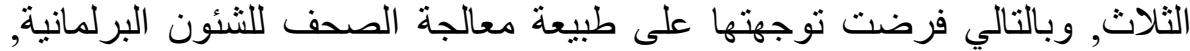

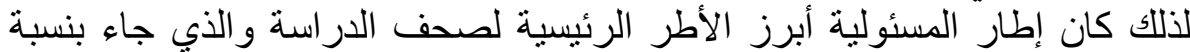

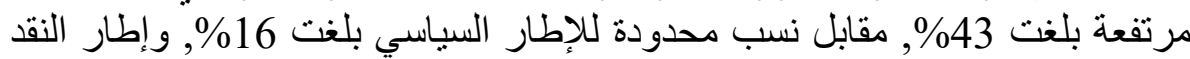
بنسبة 14\%, و إطار الصر اع بنسبة 11.6\%

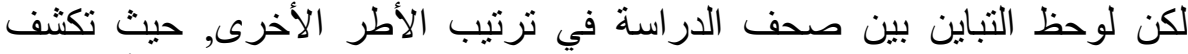

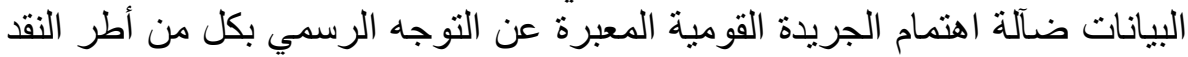

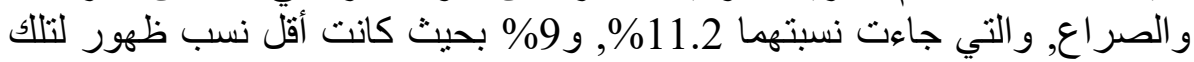


الأطر بين صحف الدراسة, في حين أن جريدة المصري اليوم أبرزت أطر النقد و الصراع بنسبة 17\%, و13.6\%, خاصة في ظل اعن اعنمادها على النو اب و والكتل

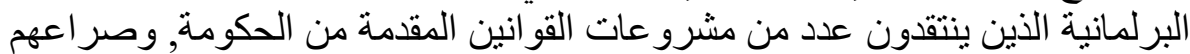

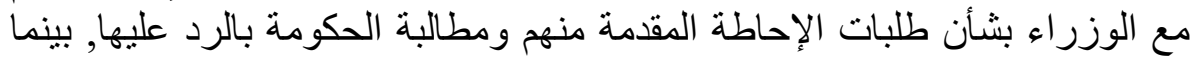

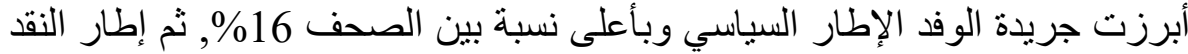

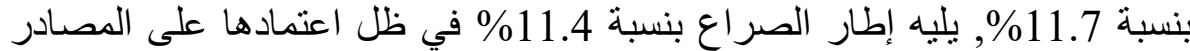

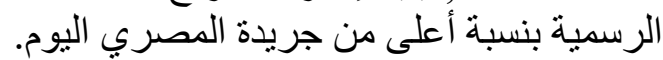

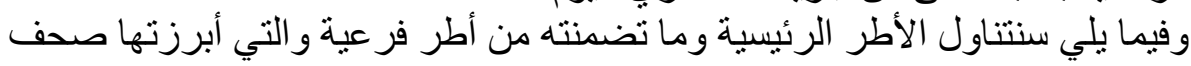

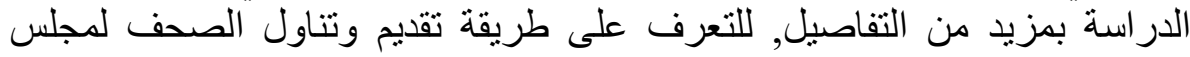

أولا: إطار المسئولية وتمثلت الأطر الفرعية المرتبطة بهذا الإطار في الإلى لئ

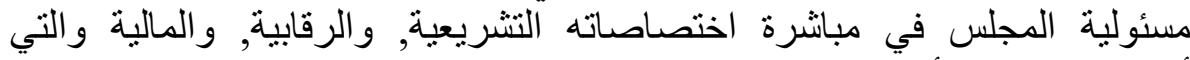

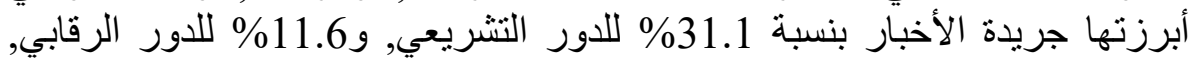

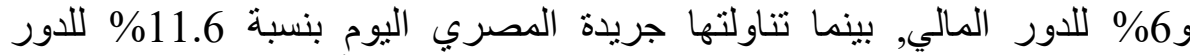

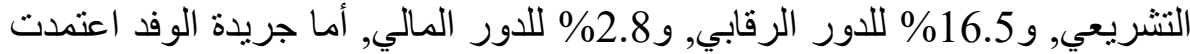

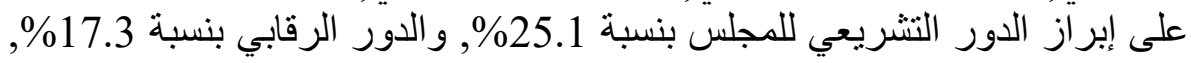
و الدور المالي بنسبة 2.8\%

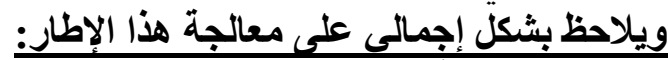

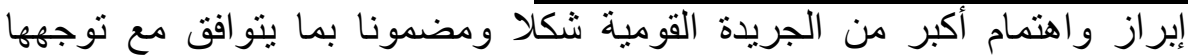

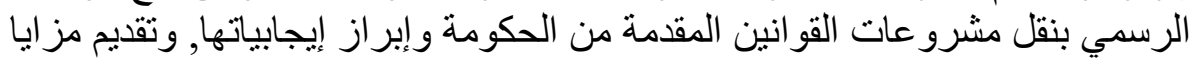

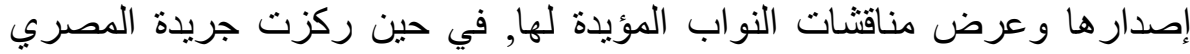

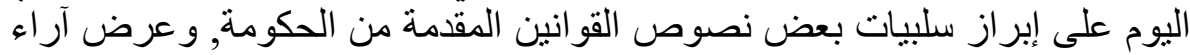

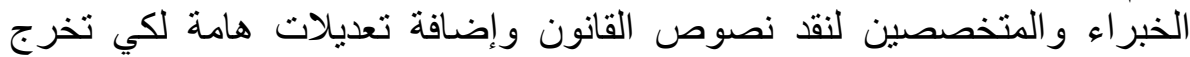

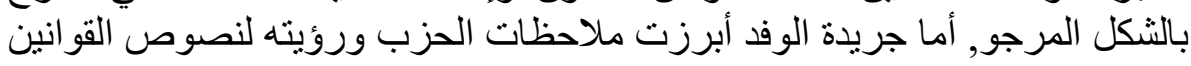

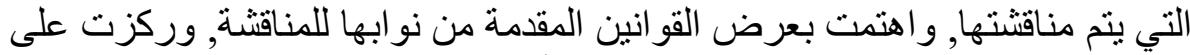
آر اء نوابها تجاه نصوص القو انين و هو ما يعد أمر ا طبيعيا بحكم طبيعة ملكيتها.

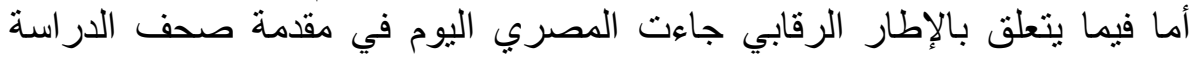

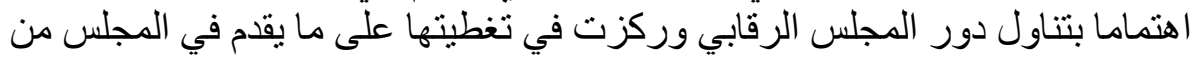

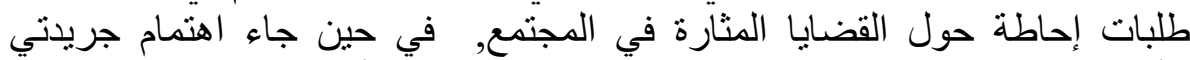

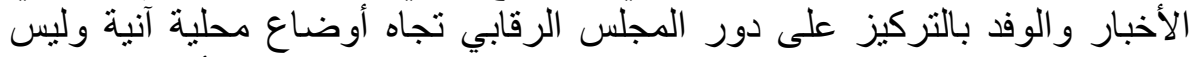

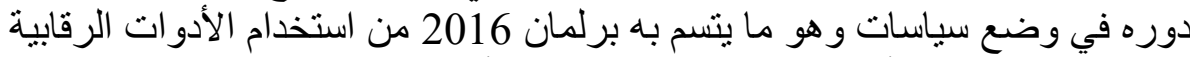

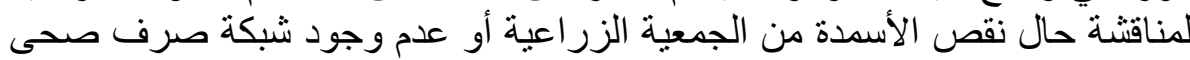

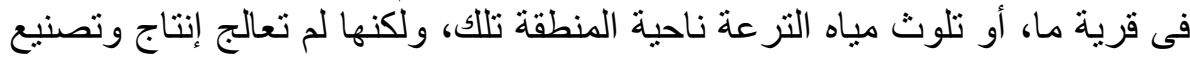




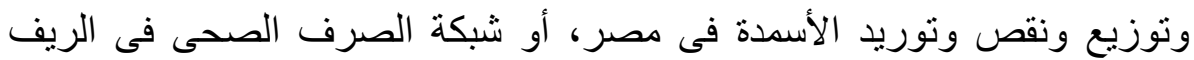

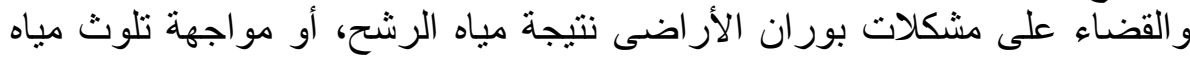

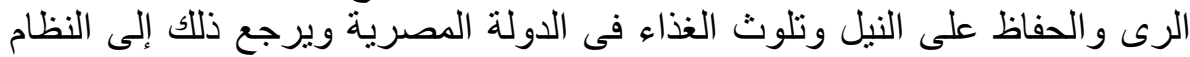

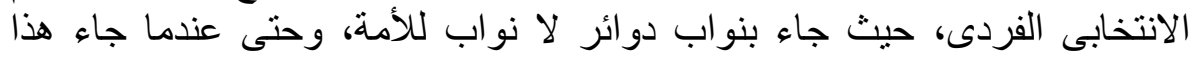
النظام بنواب قطاعات كبيرة، كانت تللك القطاعات بالقائمة المطلقة، ما جعل نو ابهاب التها

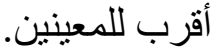
أما فيما يتعلق بإطار مسئولية المجلس في مباشرة دوره المالي اهتمت جريدة الأخبار

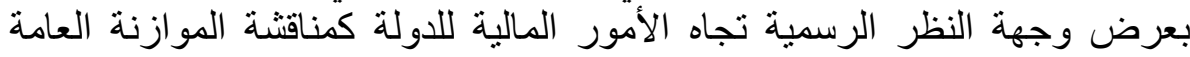

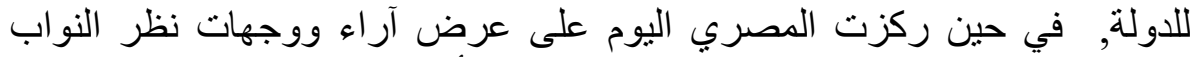

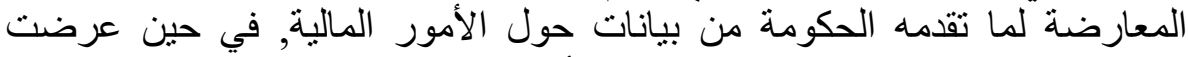
جريدة الوفد جهود نو ابها المطالبة بتحسين الأوضيان الأوضاع المالية للمو اطنين.

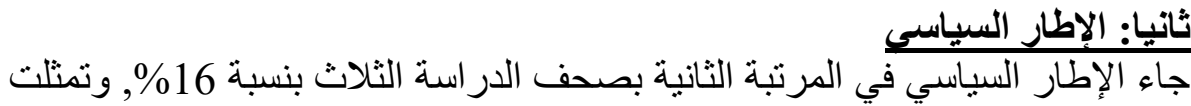

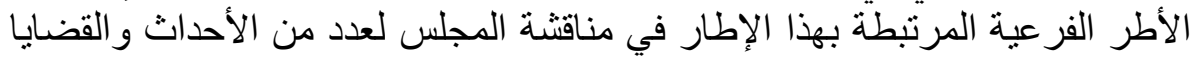

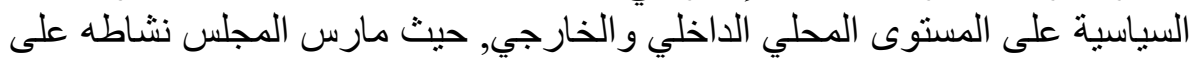

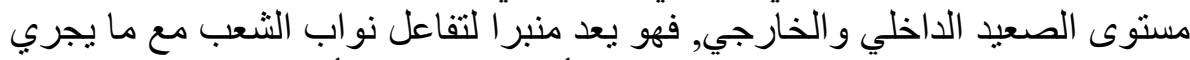

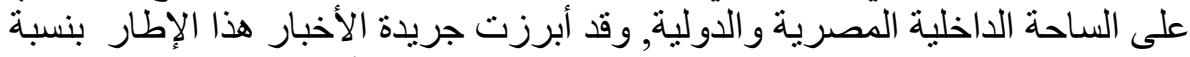

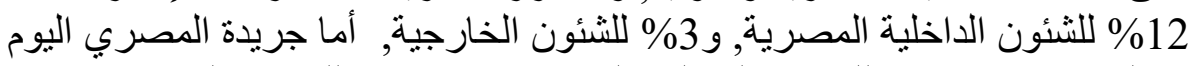

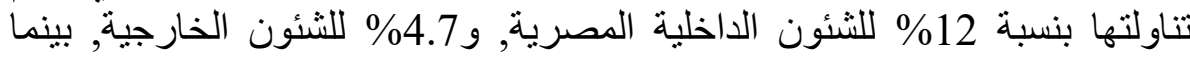

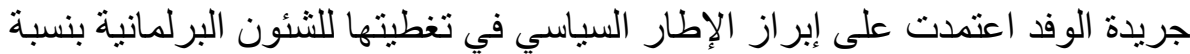

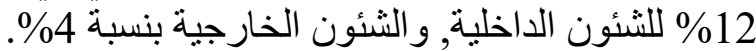

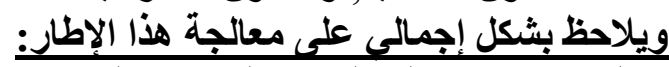

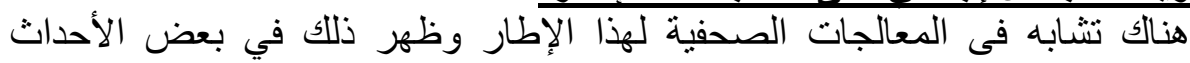

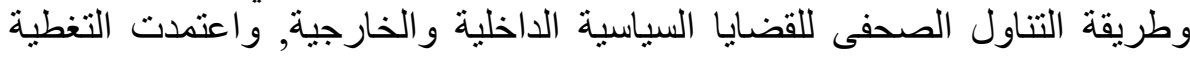

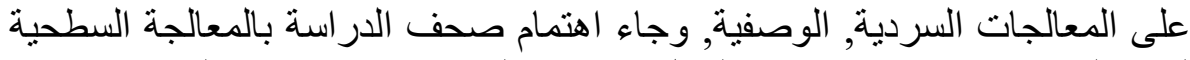

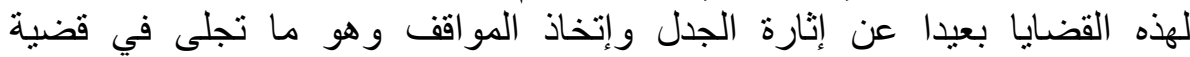

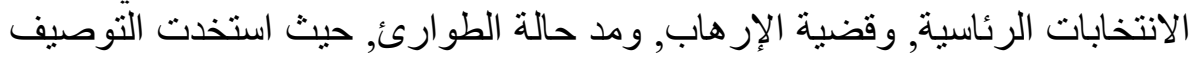

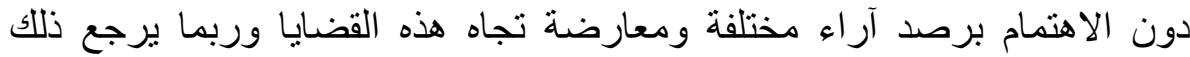
لحساسية القضايا وتعقدها. ثالثا: إطار النقاء

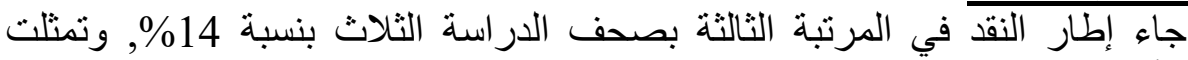

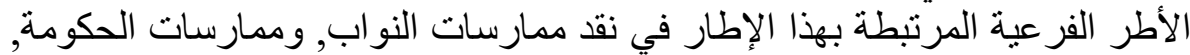

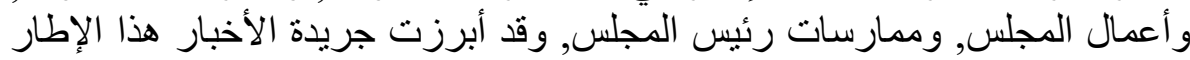

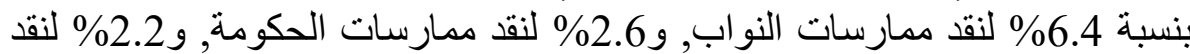
أعمال المجلس, ولم يظهر إطار نقد رئيس المجلس في جريدتي الأخبار و الوفد, أما لفار 
جريدة المصري اليوم تناولت هذا الإطار بنسبة 7.8\% لنقد أعمال المجلس, و5\% و

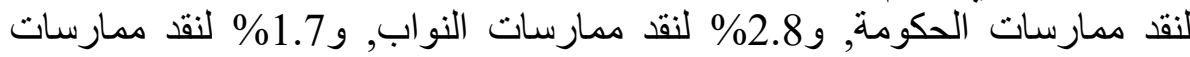
رئيس المجلس, بينما جريدة الوفد اعتمدت على إنى إبراز إطار النقد في تغطيتها للشئون

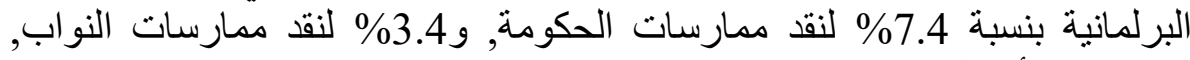

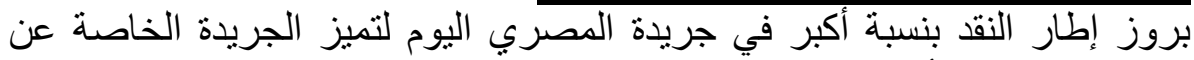

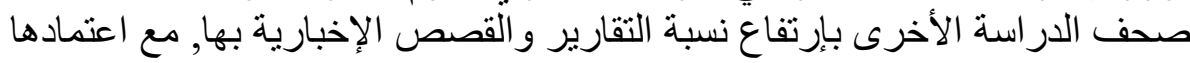

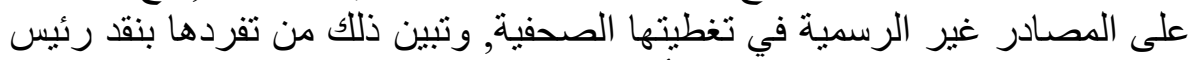

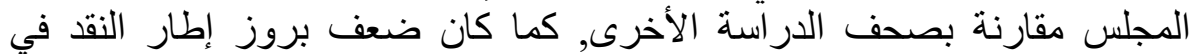

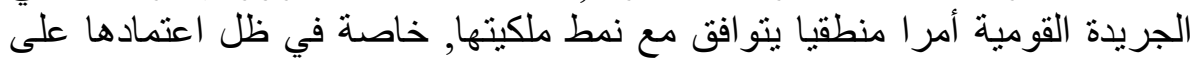

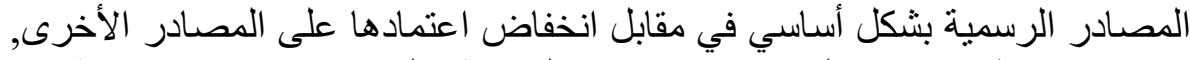

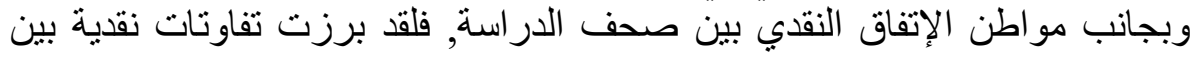

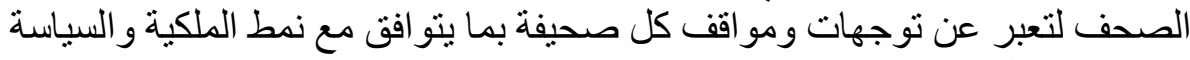
التحريرية لكل منهم. رابعا: إطار الصراع الصراع جاء إطار الصراع الصنيراع في المرتبة الرابعة بصحف الدراسة الثنلاث بنسبة 11.6\%

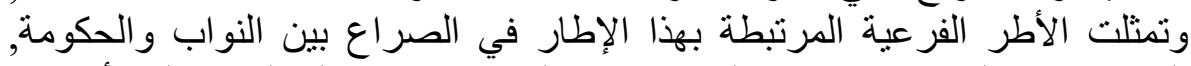

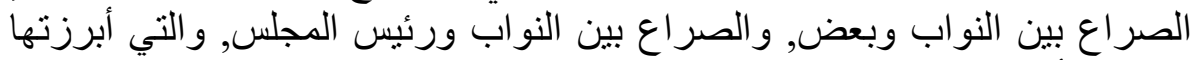

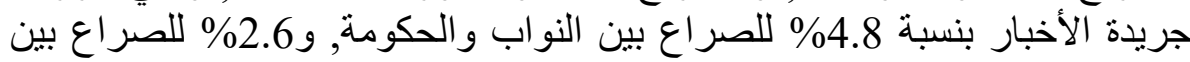

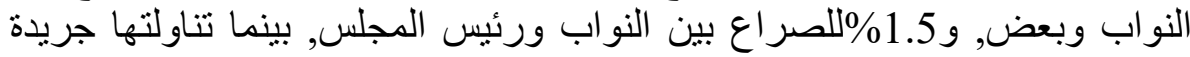

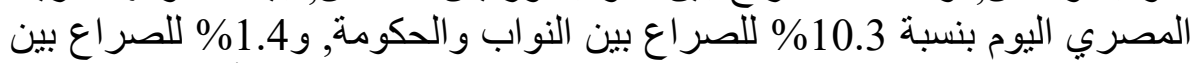

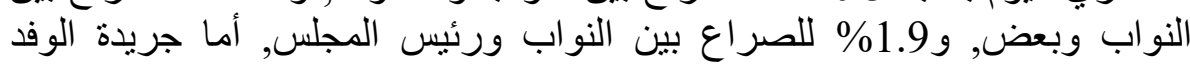

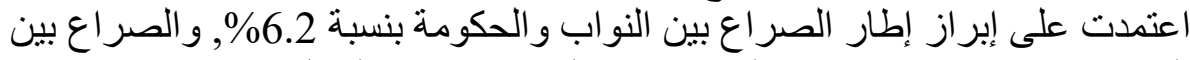

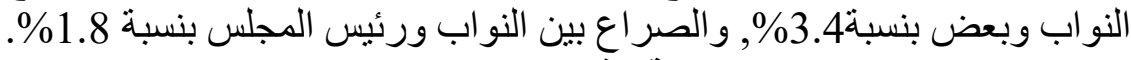

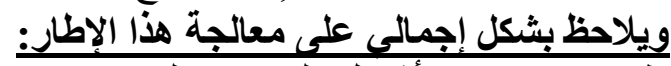

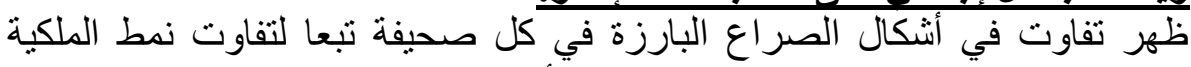

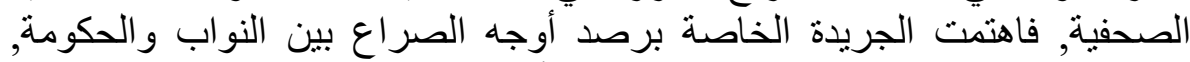

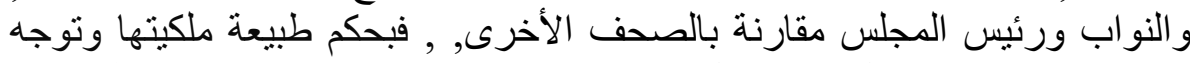

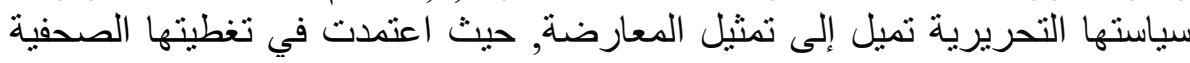

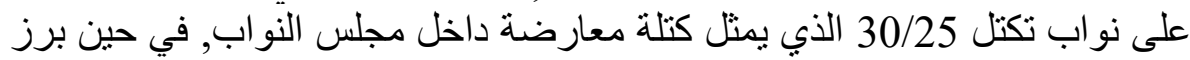

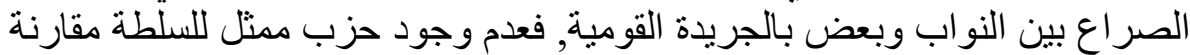

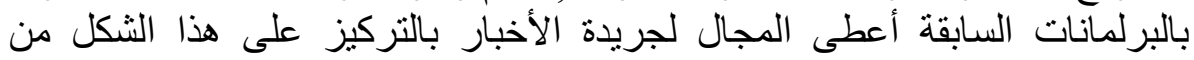

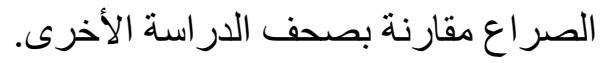


خامسا: إطار الإثارة والسخرية

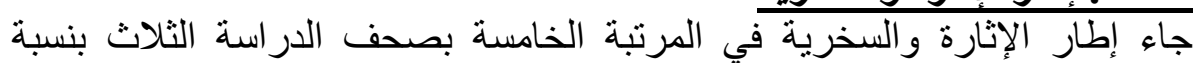

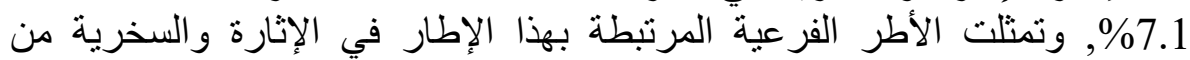

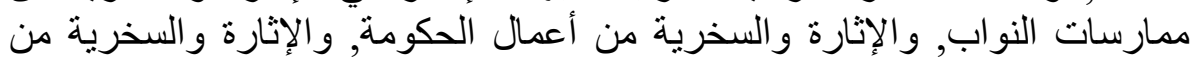

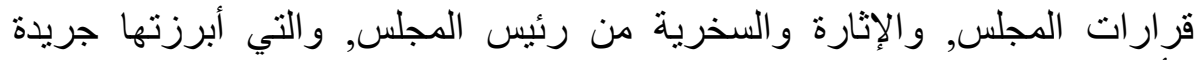

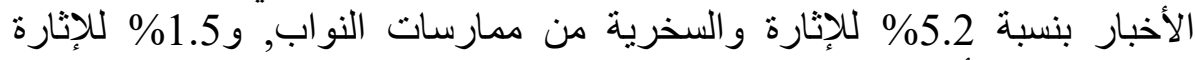

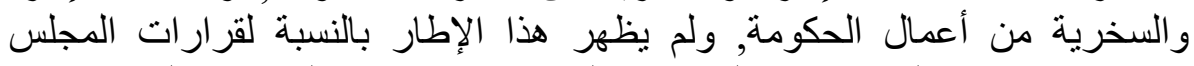

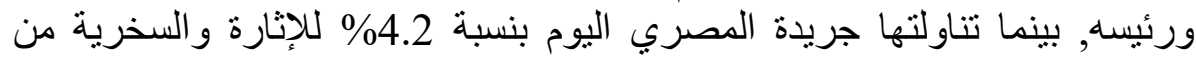

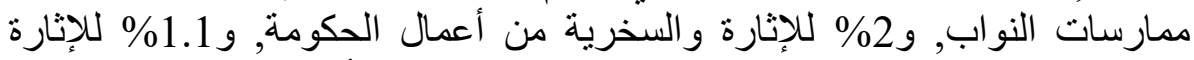

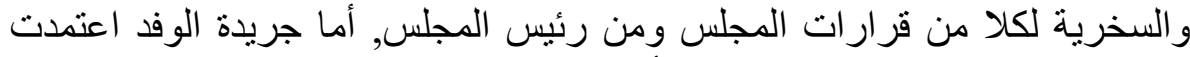

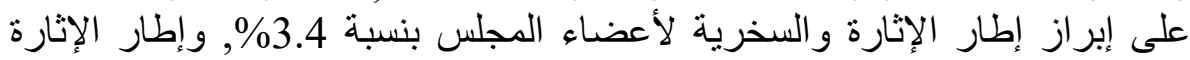

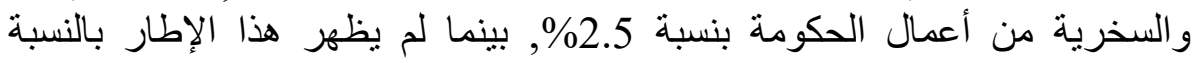
لقرار ات المجلس ورئيسا. سادسا: إطار إبراز الإيجابيات الإنيات

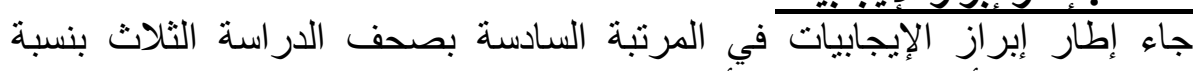

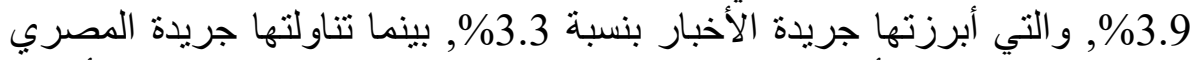

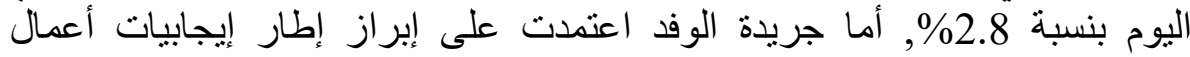
المجلس بنسبة 5.5\% \%

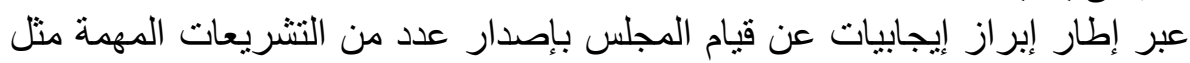

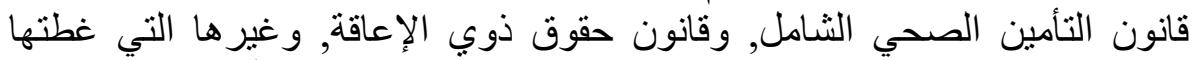

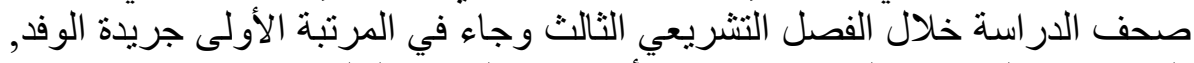
يليها جريدة المصري اليوم, ثم جريدة الأخبار في المرنبة الثئة الثالثة.

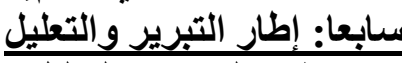

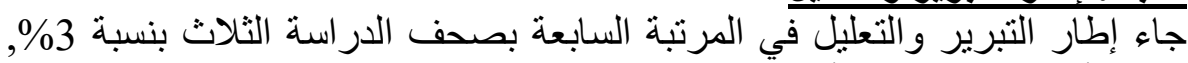

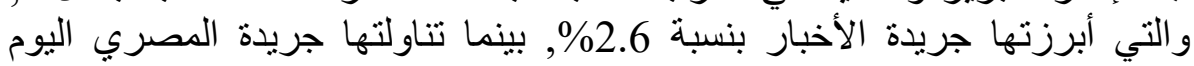

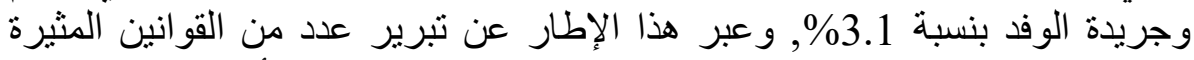

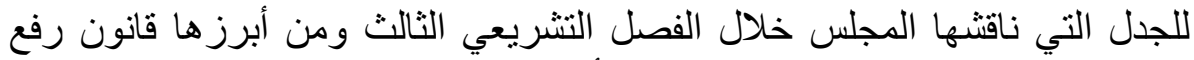

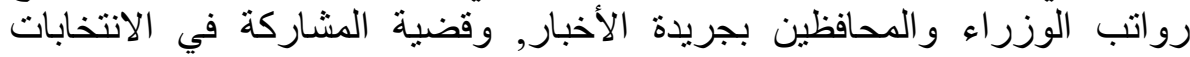

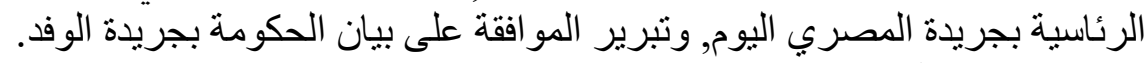

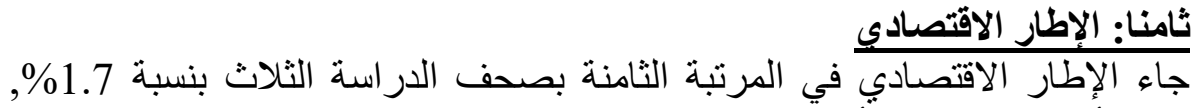

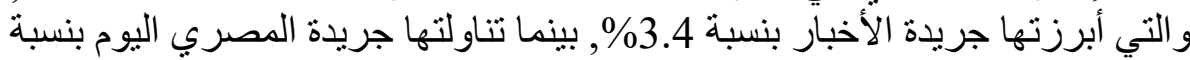

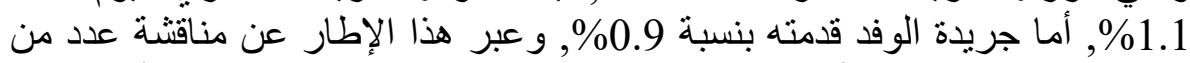
القو انين الاقتصادية التي أقرها المجلس المجل خلال الفصل التشريعي الثالث ومن أبرز ها: 
• عبر الإطار الاقتصادي بجريدة الأخبار عن مناقتة عدد من القوانين الاقتصادية

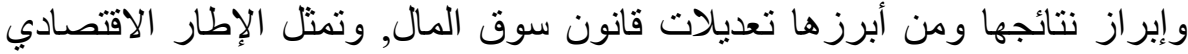

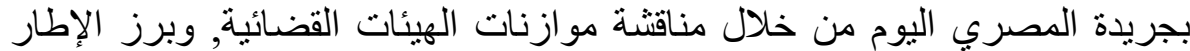

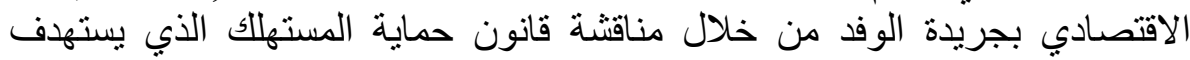
ضمان سلامة المستهلك وصحته والحصول على المعلومات و الإرشادات و الإعلان

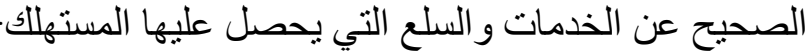

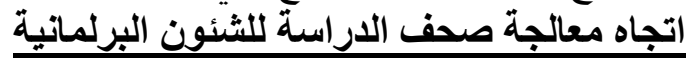

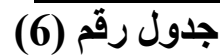

اتجاه تغطية صحف الدراسة للشئون البرلمانية

\begin{tabular}{|c|c|c|c|c|c|}
\hline الإجمالي & الوفذ & المصري اليوم & الأخبار & \multirow{3}{*}{\multicolumn{2}{|c|}{ اتجاه المعالِّة }} \\
\hline 508 & 197 & 156 & 155 & & \\
\hline$\% 53.6$ & $\% 61$ & $\% 43.5$ & $\% 58.1$ & & \\
\hline 221 & 80 & 103 & 38 & 5 & \multirow{2}{*}{ سلبي } \\
\hline$\% 23.3$ & $\% 24.8$ & $\% 28.8$ & $\% 14.2$ & $\%$ & \\
\hline 219 & 46 & 99 & 74 & 5 & \multirow{2}{*}{ غير محلد } \\
\hline$\% 23.1$ & $\% 14.2$ & $\% 27.7$ & $\% 27.7$ & $\%$ & \\
\hline 948 & 323 & 358 & 267 & 5 & \multirow{2}{*}{ الإجمالي } \\
\hline \%100 & $\% 100$ & $\% 100$ & \%100 & $\%$ & \\
\hline
\end{tabular}

(كا2=27.212، درجة الحرية=4، مستوى المعنوية=0.000، معامل التو افق=0.167)

يوضح الجدول اتجاه التغطية الصحفية للشئون البرلمانية في صحف الدر اسة, و الذي الذي التئة التئة يكثف عن غلبة النبرة الإيجابية في تغطية صحف الدارية التهة عن النبرة السلبية

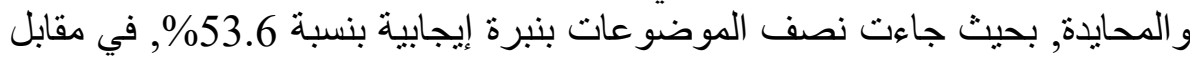
نسبة 23.3 \% للاتجاه السلبي, و 23.1\% للاتجاه المحايد, وهو ما يعكس إتجائا إيجابيا من صحف الدر اسة نحو مجلس النواب أكبر من الاتجاه السلبي و المحايد.

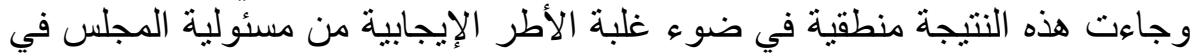

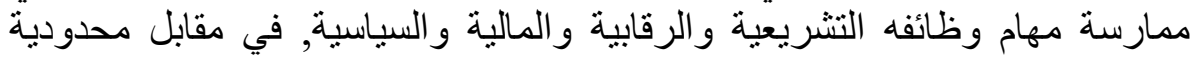
الأطر السلبية من نقد وصر اعلة وسخرية. وتختلف هذه النتيجة مع نتائج دراسة ونة سمر حسن الطبلاوي 41, ودر اسة إيمان عصام

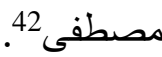

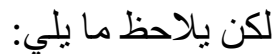

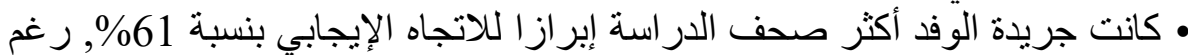

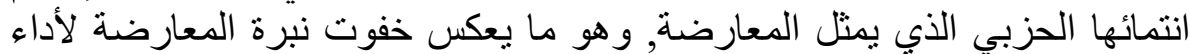

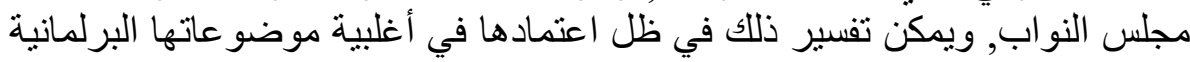

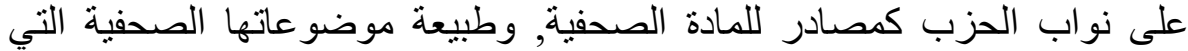
اهتمت بإبراز دور الحزب بالمجلس من تقديم مشروعات قوانية قوانين وطلبات إحاطة, و هو ما يعد أمر ا طبيعيا بحكم ملكيتها. 
• كانت جريدة الأخبار أقل صحف الدراسة إبرازا للاتجاه السلبي بنسبة 14.2\%

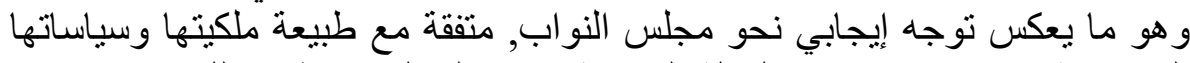

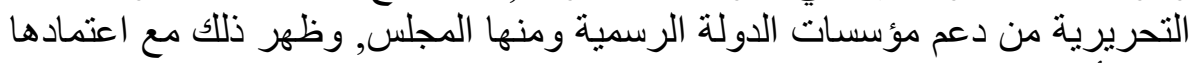
بشكل أساسي على المصنس دئ دوبر الرسمية.

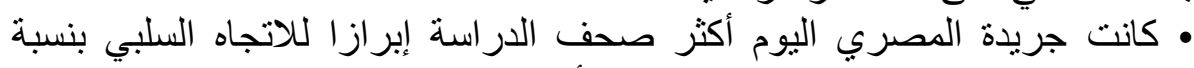

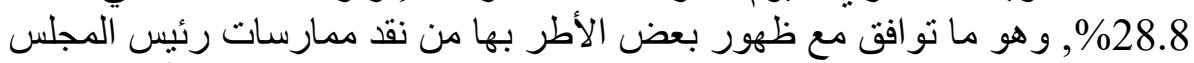

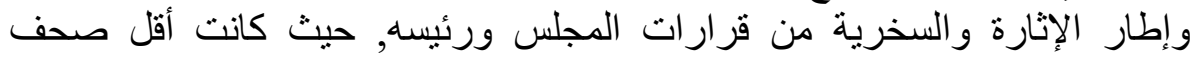

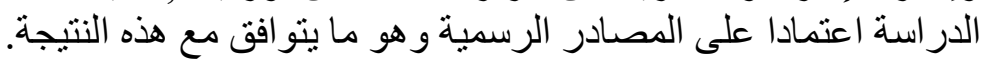

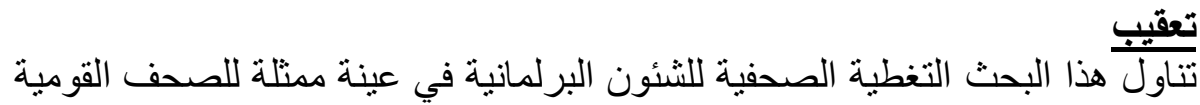

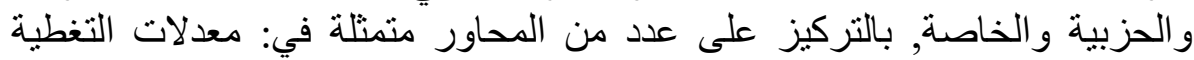

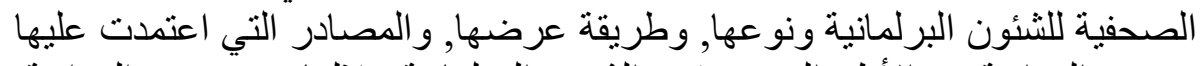

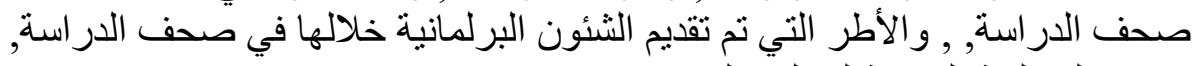

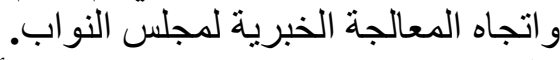
وقد توصل التحليل إلى عدد من النتائج أهمها:

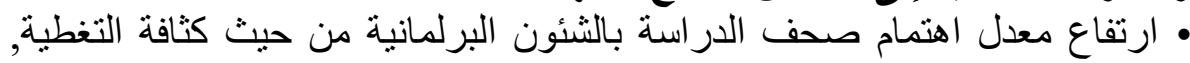
وطرحها في المواقع البارزة بالجريدة, بحيث لم يتم الإكتفاء بنشر ها في في الصنة الصفحة

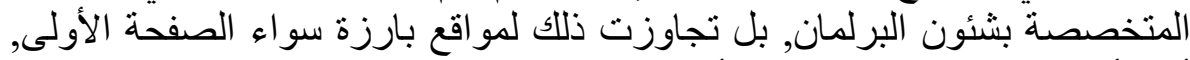

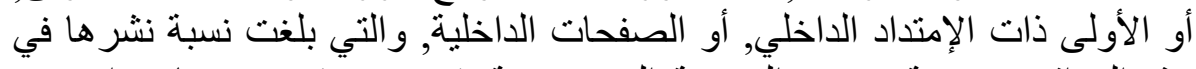

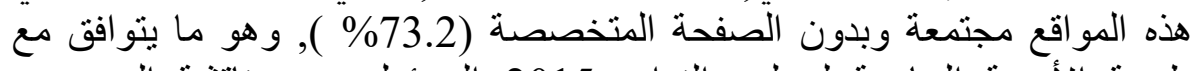

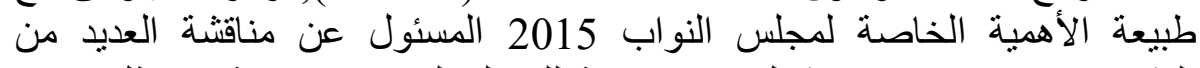
التشريعات و إقرار ها مما يشكل مادة خصبة للتبلة للتناول الصحفي خاصة في ظل فيامها بوظيفة الإخبار بصفة أساسية.

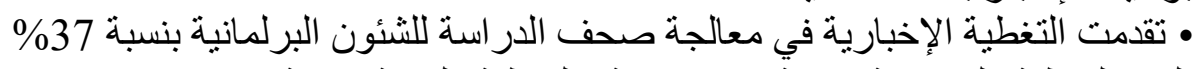

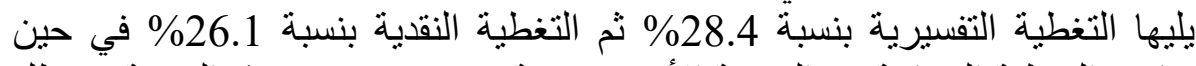

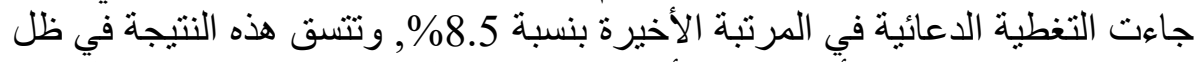

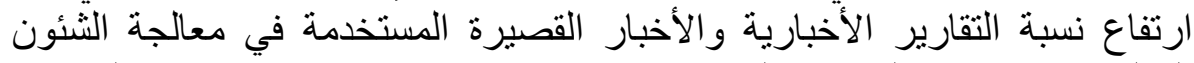

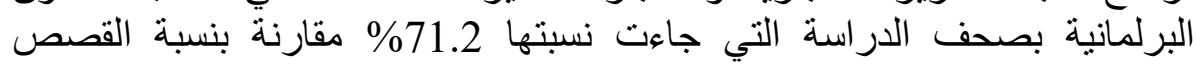

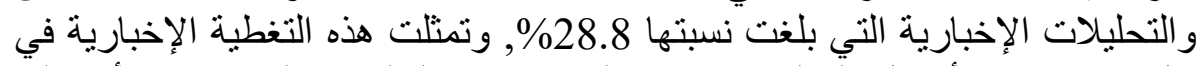

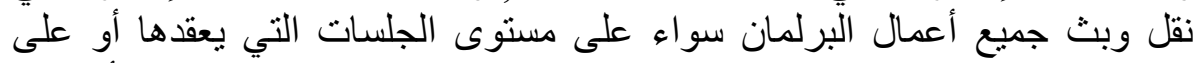

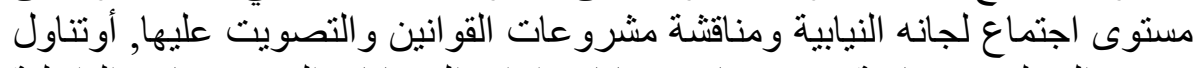

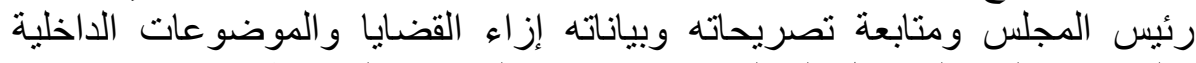

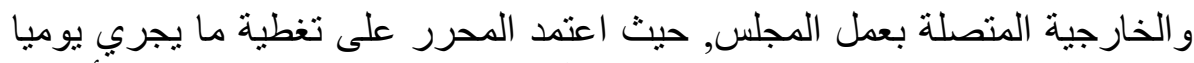

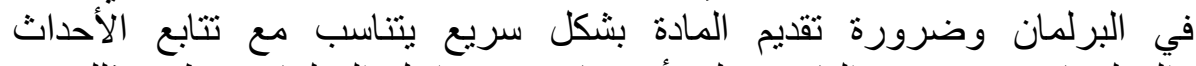
و ألمعلومات حتى يقف القارئ على أهم ما يجري داخد الثل البرلمان. وظهر ذللك من 


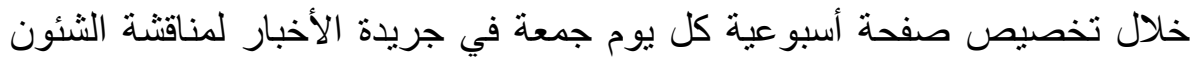

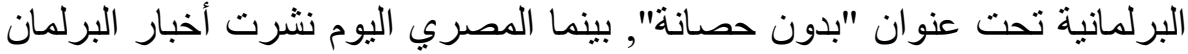
في صفحة "قضايا ساخنة", وتم تغطية الثئون البرلمانية في جريدة الونية الوفد في صفحة تحمل عنوان "أوراق برلمانية". • اتفقت صحف الدراسة الثلاث في تصدر القضانة التضايا التشريعية قائمة قضايا مجلس النواب خلال فترة الدراسة وذللك بنسبة 41.1\%, بليها القضايا الرقابية بنسبة

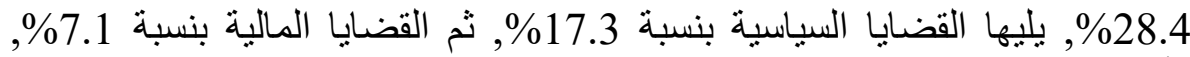

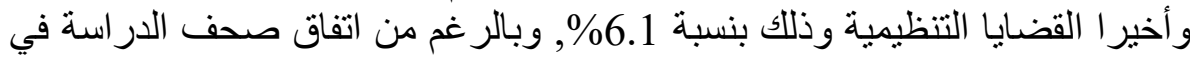
معدل الاهتمام بالقضايا لكن اختلفت نوعية هذه القضايا وطريقة تناولها لها وفقا لتوجهات كل جريدة و السياسة التحريرية الخاصة بالفة بها.

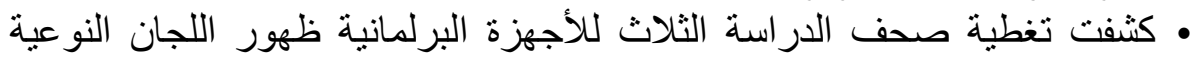

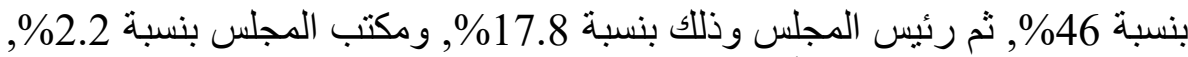

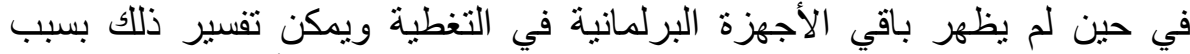
حصول كل من الاختصاص الرقابي والتشريعي للمجلس على الإنى أعلى نسب التبل التغطية

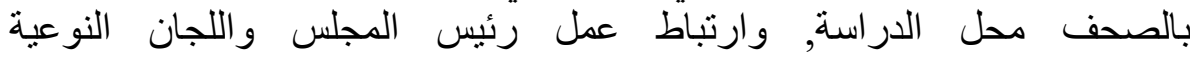

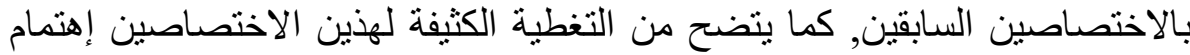

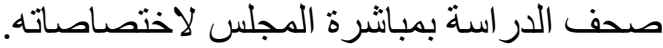

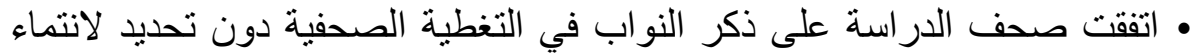

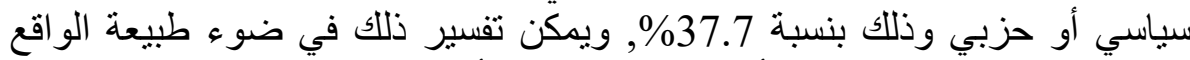

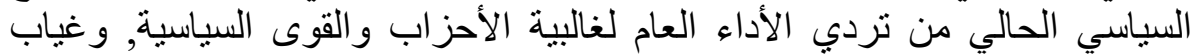

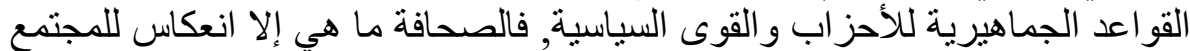

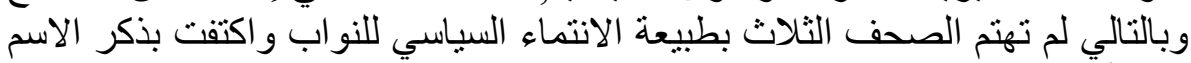

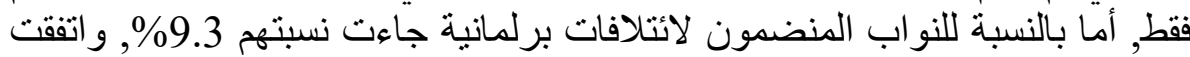
صحف الدراسة على تغطية النواب المنتمين لائتلاف دعم مصر و

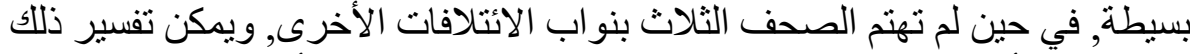

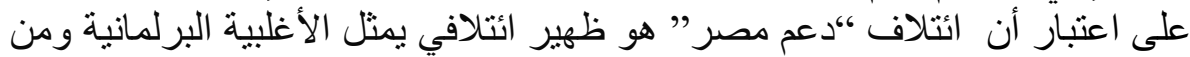

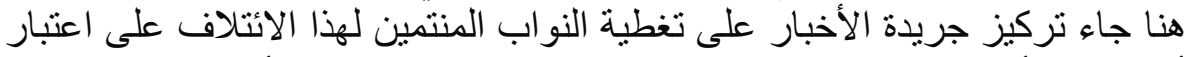

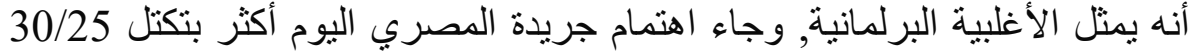

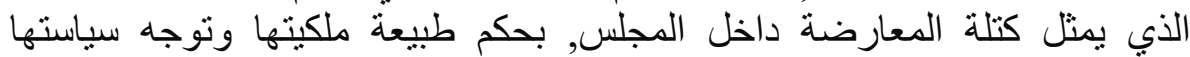

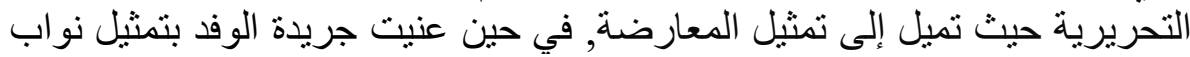
الحزب و هو ما يعد أمر ا طبيعيا ومقبو لا بحكم طبيعة ملكيتها.

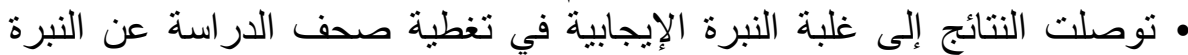

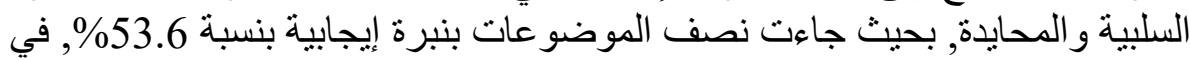
مقابل نسبة 23.3 \% للاتجاه السلبي, و 23.1\% للاتجاه المحايد, و هو ما يعكس إتجاها إيجابيا من صحف الدراسة نحو مجلس النواب أكبر من الاتجاه السلبي والمحايد, 


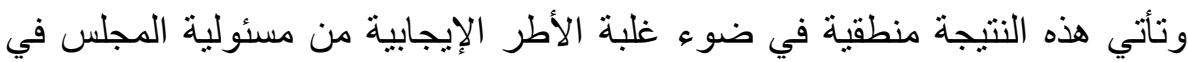
ممارسة مهام وظائفه التشريعية والرقابية و المالية و السياسية, في مقابل محدودية الإية الأطر السلبية من نقد وصر اعلة وسخرية.

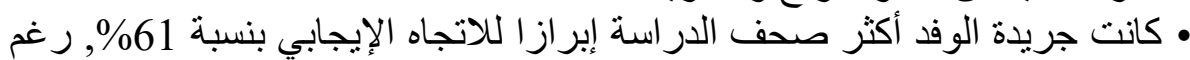

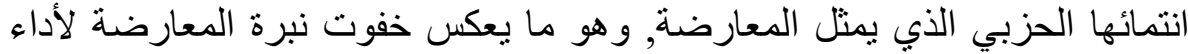

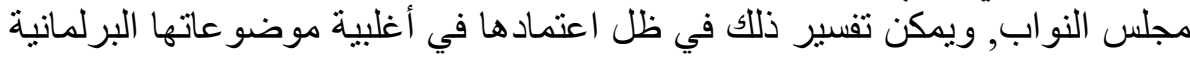

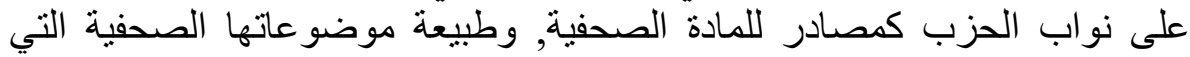

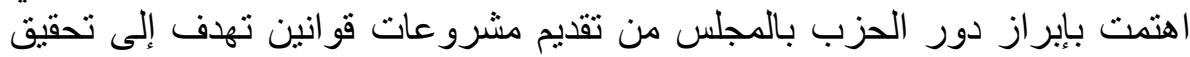

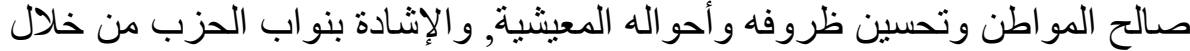

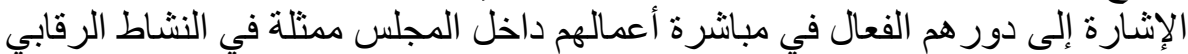

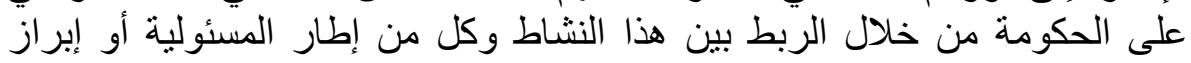

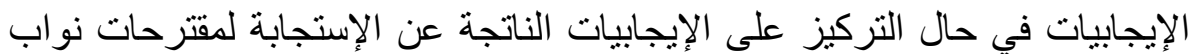

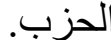

• كانت جريدة الأخبار أقل صحف الدراسة إبراز اللاتجاه السلبي بنسبة 14.2\%

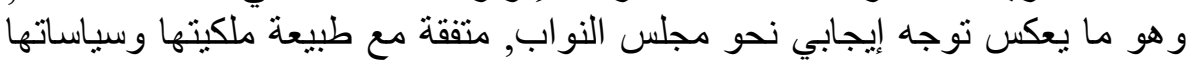
التحريرية من دعم مؤسسات الدولة الرسمية ومنها المجلس, وظهر ذلكية للك مع اعتمادها بشكل أساسي على المصنس دعادر الرسمية.

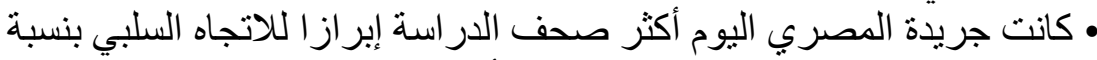

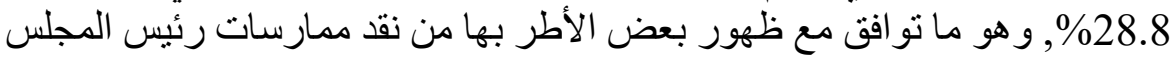

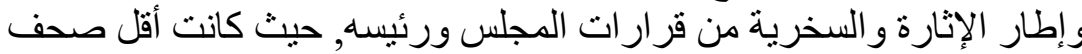
الدر اسة اعتمادا على المصادر الرسمية وهو ما يتو الفق مع هذه النتيجة. 
(1)-Peter J.Okello, "The Media and Parliament: Creating Effective Linkages for Dem ocracy Media Coverage of the Parliament of Ugand", Master, (Saint Mary's

University, 2003).

(2)-van Santen, R., Helfer, L. \& van Aelst, P. "When politics becomes news: An analysis of parliamentary questions and press coverage in three West European countries", (Acta Polit, 50, 45-63 (2015). DOI:https://doi.org/10.1057/ap.2013.33.

(3) - Pieter de Wilde, "No effect, weapon of the weak or reinforcing executive dominance? How media coverage affects national parliaments' involvement in EU policyformulation",(ComparativeEuropeanPolitics, $\quad 9(2$ JDOI:https://doi.org/10.1057/cep.2009.13

(4)- Rens Vliegenthart and Noemi Mena Montes, "How Political and Media System Characteristics Moderate Interactions between Newspapers and Parliaments: Economic Crisis Attention in Spain and the Netherlands", (The International Journal of Press/Politics, 2014), Vol. 19(3) 318-339.

(5)-Mankler, Anders, " Professors, papers and parliaments: How the media affects politicians' references to research", Master, UPPSALA UNIVERSITET, 2015), P.48.

(6)-Elinor Chisholm, "Mps, The Media ,and The Televising of Parliament", ( Political Science, L. 57, No. 2, December 2005).

(7)-Pieter de Wilde, "Media coverage and National parliaments in EU policy-FormulationDebast on the EU Budget in the Netherlands 19922005", (the ECPR Graduate Conference, Universitat Autonòma de Barcelona, Barcelona, 26 August 2008). 
(7)- عبد المجيد عرسان العزام وفاروق العزام, ". اتجاهات الأردنيين نحو الاداء البرلماني

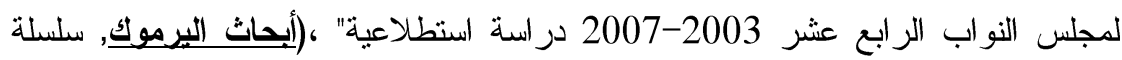

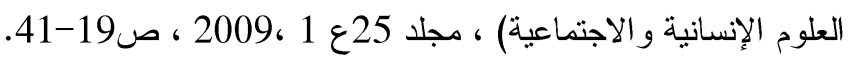

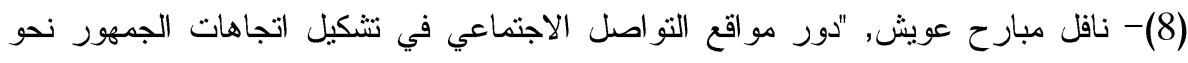

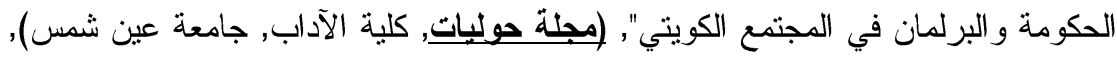

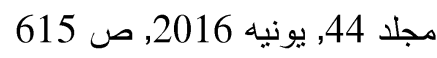

(9)- محمود محمد محمود مسلم, "أطر معالجة الصحف المصرية لقضايا البرلمان

المصري(مجلسي الثعب و الثورى 2012-2013)", رسالة ماجستير غير منشورة، (كلية

$$
\text { الآداب, قسم الاعلام، جامعة الزقازيق), 2016, ص289 } 2810 .
$$

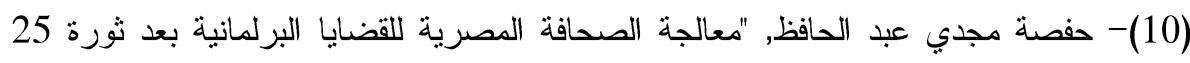

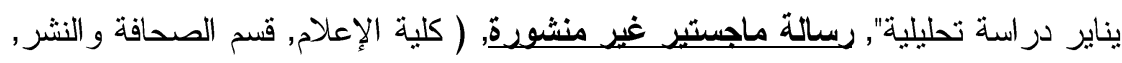

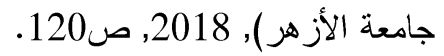

(11)- رؤى محمد أبو الفضل بدران, "أطر معالجة الصحف المصرية للقضايا بمجلس النواب

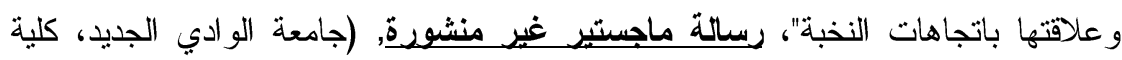

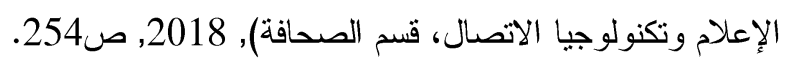

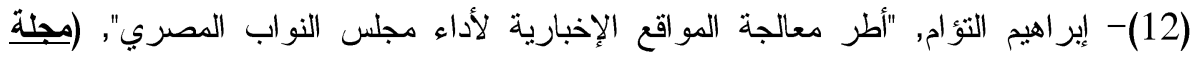

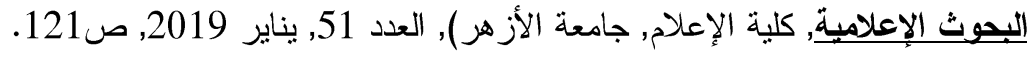

$$
\begin{aligned}
& \text { (13)- حفصة مجدي عبد الحافظ, مرجع سابق, ص310. } \\
& \text { (14)- إبر اهيم التؤ ام, مرجع سابق, ص صد } 122 \text { (13) }
\end{aligned}
$$

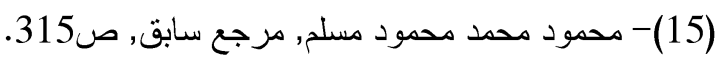

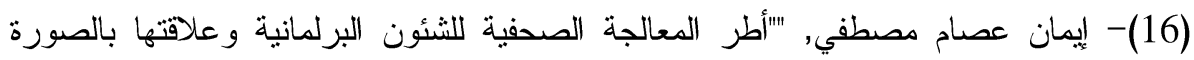

الذهنية لمجلس الثعب لدى الجمهور", رسالة ماجستير غير منشورة, (جامعة القاهرة, كلية

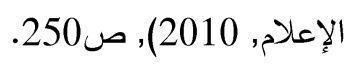

(17)-Nicolas Bouchet, Nixon K.Kariithi, "Parliament and the media building an informed society",(The International Bank for Reconstruction and Development /The World Bank), Washington, D.C. 20433, U.S.A, 2003. 
(18)-Douglas Bicket, "Media constructions of scoittish national identity though the prism of the new Scottish parliament", (Barcelona, Barcelona, Phd, University of Washington, 2001).

(19)- سلام أحمد عبده, "صفحة الثئئن البرلمانية في الصحافة القومية دراسة للمضمون و القائم

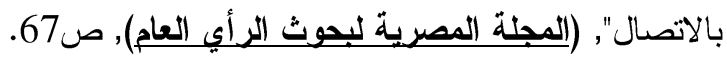

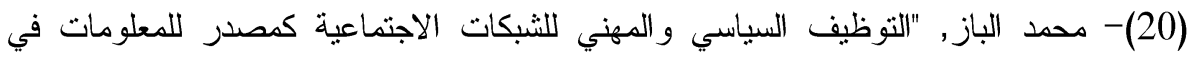

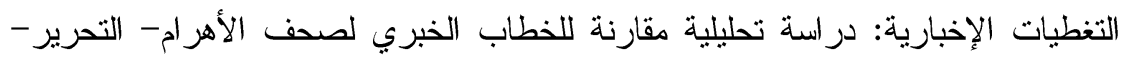

و الحرية والعدالة في تغطية برلمان الثورة, رؤية مستقلية", (المجلة المصرية لبحوث

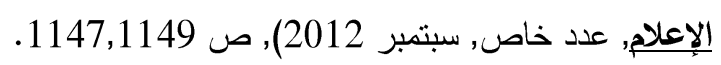

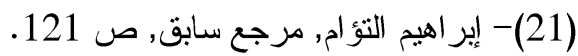

(22)- نشوي عقل, "التغطية التليفزيونية و الصحفية للقضايا البرلمانية ودور ها في تنكيل اتجاهات الجمهور العام نحو البرلمان", رسالة دكتوراه غير منشورة, (كلية الإعلام, جامعة القاهرة,

$$
\text { 2006), صن350. }
$$

(23)- محمود حمدي شعبان, "صورة النخبة السياسية في الفضائيات المصرية نحو أداء مجلس

النواب المصري وعلاقتها باتجاهات الجمهور", رسالة ماجستير غير منشورةٍ (كلية

$$
\begin{aligned}
& \text { الآداب, قسم الإعلام, جامعة المنصورة), 2017, ص352. } \\
& \text { (24)- عاطف محمد, مرجع سابق, ص265. }
\end{aligned}
$$

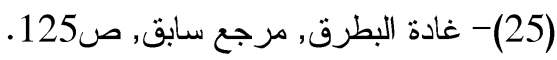

$$
\begin{aligned}
& \text { (26)- دينا وحيد, مرجع سابق, } 299 .
\end{aligned}
$$

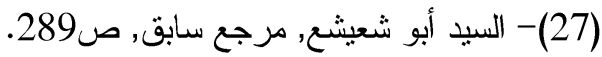

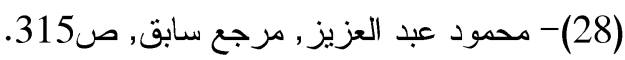

$$
\begin{aligned}
& \text { (29)- سارة شريف, مرجع سابق, ص235. }
\end{aligned}
$$

(30)- Barker, G.G, Op.cit, pp.22.

(31)- زينب حسن, "صورة الإسلام كما تعرضها المواقع العربية على شبكة الانترنت", رسالة

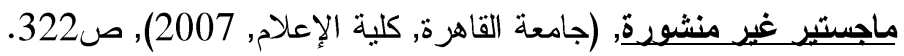

(32)- Nelson, E.T, "What is the issue? Legal and constructions and political attitudes, paper presentedat at the American political science association annual meeting, Boston, MA, 2001, pp.1-21. 
(33)-S.H. chaffee,s.f Kanian," learning about politics from the mass media", (Political Communication, 104,1997),p:428.

$$
\begin{aligned}
& \text { " وهؤلاء المحكمون هم: } \\
& \text { 1.د/ سليمان صالح أستاذ الصحافة بكلية الإعلام جامعة القاهرة } \\
& \text { ا.د/ هشام عطيه أستاذ الصحافة بكلية الإعلام جامعة القاهرة } \\
& \text { ا.د/ أمل السيد أستاذ الصحافة بكلية الإعلام جامعة القاهرة }
\end{aligned}
$$

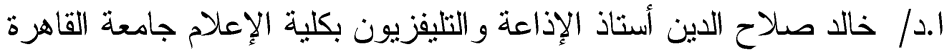

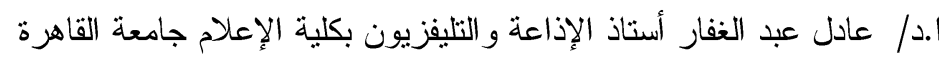

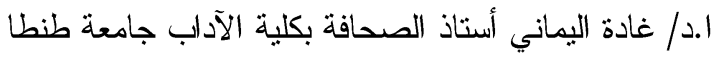

$$
\begin{aligned}
& \text { د/ شيرين سلامة أستاذ مساعد بقسم الصحافة بكلية الإعلام جامعة القاهرة } \\
& \text { د/ محمد منصور هيبه مدرس الصحافة بكلية الإعلام جامعة القاهرة }
\end{aligned}
$$

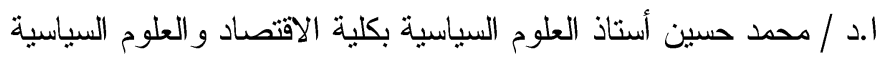

د./ أمل حماده أستاذ مساعد بقسم العلوم السياسية بكلية الاقتصاد و العلوم السياسية جامعة القاهرة

(35)-Robet Entman, "cascading Activation: Contesting the white House

Frame after 9/11", (Political communication, vol.20, No.4, 2003, p.417.

(36)-Stanly J.Baran, Dennis K. Davis, "Mass communication Theory

Foundation, Ferment, and Future", (united States, Wadsworth, Sixty Edition, 2012), p.390-400.

(37)_GangHeong Lee," Reconciling 'Cognitive Priming' vs 'Obtrusive Contingency' Hypotheses An Analytical Model of Media AgendaSetting Effects", (Management Communication Quarterly, 2009) P.473-501.

(38)-Jon A.Krosnick, Donald R.Kinder, Op.Cit, P.495.

$$
\begin{aligned}
& \text { 39- إبر اهيم التو ام, "أطر معالجة المو اقع الإخبارية لأداء مجلس النواب المصري", (مجلة البحوث }
\end{aligned}
$$

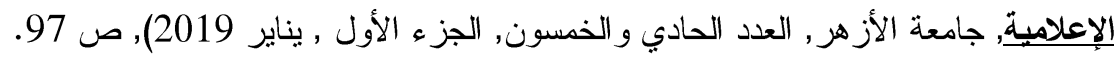

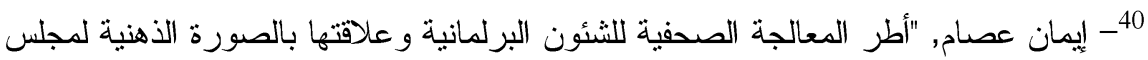

$$
\begin{aligned}
& \text { الثعب لدى الجمهور", رسالةّ ماجستير غير منشورة, (جامعة القاهرة, كلية الإعلام, } \\
& \text { 2012), ص245. (2012 }
\end{aligned}
$$


